SB 381

.R67

Copy 1
A MANUAL ON THE

TRE OF SMALL FRUITS.

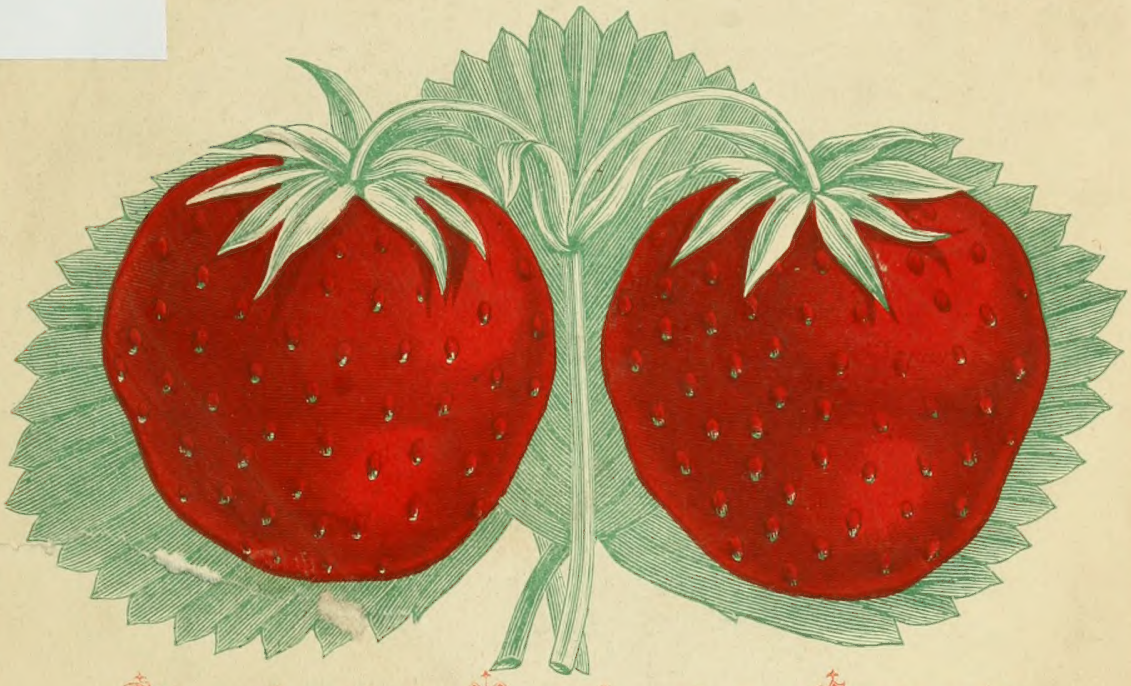

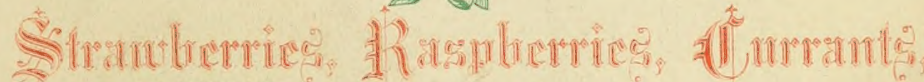

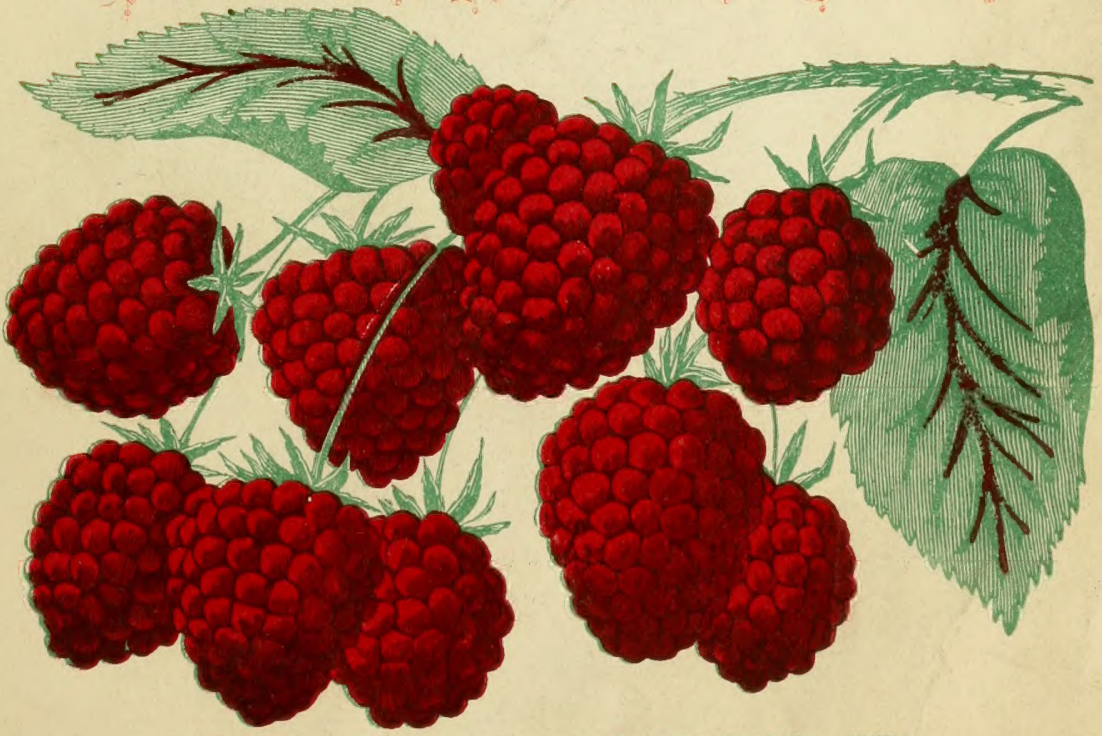

GOOSEBERRIES, BLACKBERRIES, ETC.

How to Raise and Market Them.

P R I G

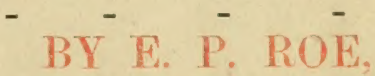

50 CENTS.

Author of "Play and Profit in my Garden," "Barriers Burned Away," "Opening a Chestnut Burr," "From Jest to Earnest," Etc. 



\title{
al atrammal
}

\author{
an the
}

(1) ulture of Small effrmits,

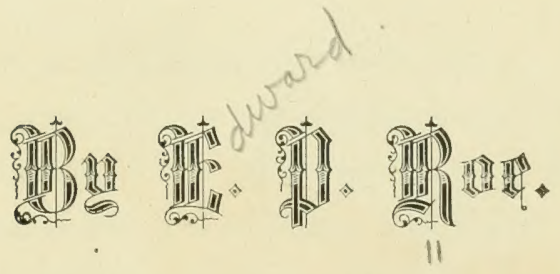

आरून

COPYRIGIT, 1876, BY E. P. ROE.

यक्रण5

N E W B U IR GH, N. Y. :

JOURNAL PRINTING ESTABLISIMIENT,

$18 \% 6$. 


$$
\begin{gathered}
S B 381 \\
\text { R67 }
\end{gathered}
$$




\section{AN OPEN LETTER。}

TO THE REA DER.

T. AVING received so many and varied questions concerning the culture of small fruits, especially strawberries, and finding it quite impossible to answer them separately, by letter, I have been led to reply by the following brief manual.

At the same time I shall aim to do more. This is a busy age, and neither time nor money is abundant. There are multitudes who would gladly see upon their tables the relicious berries in their season, and if they knew how easily and readily they could be raised, would certainly cultivate them. But having made some crude experiments with but poor, or partial success, they come to think that some mystery is involved and that before they can grow small fruits themselves there must be considerable outlay, reading or practical instruction. But nature is not so chary of her best gifts and, like the sunshine, she places strawberries within the reach of all who own or hire a few square feet of land.

While the rich amateur with his trained gardener, and the practical and scientific fruit-grower by his skill can secure remarkable results, I shall try to show the hurried professional and business man, the driving farmer, the lady rurally inclined, that they, by a little knowledge and labor, can readily supply 
the home market with the most wholesome of summer food. I use the word food advisedly-food that can sustain hard work, for during their season I almost live upon berries, and I have but few idle moments. I shall endeavor to give some instruction concerning the culture of small fruits so simply and clearly that one who has never seen them, can go to work intelligentlyand so concisely that an hour's reading or less will prepare for this work. But let no one think that he can master the science of small-fruit culture in half an hour or half a life-time. I have been studying the subject for years with enthusiasm, and feel that I am yet but on the threshold of its knowledge. Charles Downing and A. S. Fuller would be the last men in America to say that they knew it all, and yet few know as much about every phase of horticulture. I have reference to the practical knowledge needful to secure a simple and definite end. We would all be in a woful plight if we had to teach our cooks the whole science of chemistry before they could give us a batch of sweet, light bread.

For the ordinary purposes of the garden and market there is no mystery involved. Ill-success usually arises from the lack of a little practical knowledge and from neglect-or from leaving the care of the plants to the "hired man" who may have an antipathy to everything save cabbages and potatoes.

But a fraction of the money that supplies a household from the market with fruit that is often but half ripe or half decayed, would stock the garden with the choicest varieties.

Besides, the most delicate and luscious kinds are the most easily grown usually. But they are not often found in market because too soft for transportation. They may be picked from our own gardens daily with the dew upon them.

The Editor of the American Agriculturist writes with a 
great deal of force-_" The unfortunate people who buy their fruit do not know what a strawberry is."

To teach as many as possible who own a little land what a "Charles Downing," a "Triomphe de Gand," or some other luscious strawberry is, directly from their own vines, is one of the objects of this manual.

At the same time I have some hope that the following pages may contain suggestions of value to those who, like myself, are engaged in raising small fruits upon a large scale. I have carefully consulted the best authorities. I have closely questioned successful and practical growers, and have had some experience myself, reaching through a number of years and a fair degree of success, as the following testimonials may prove:

Strawberries-WHAT Downing SAYs. - There is probably no higher authority upon fruit than CHARLEs DowniNg, Esq., and having seen the nine varieties exhibited by Rev. E. P. Roe, at D. Smith's bookstore, said that he had never seen as fine a collection, take them altogether, though he had seen as fine specimens of single varieties. They are the Monarch of the West, Champion, Triomphe de Grand, Jucunda, Seth Boyden, President Wilder, Late Prolific, Charles Downing, and Lenig's White.Newburgh Daily Journal.

We have seen and tasted some of the finest strawberries from the prolific gardens of Rev. E. P. Roe, Cornwall : in size enormous, in quality admirable, and in aburidance of yield extraordinary. The culture of this fruit is so easy and the result so great, we wonder that every family in the country does not have its strawberry bed. ['The fruit was shown to Dr. S. I. Prime.]-New York Observer.

Delicious Strawberries. - The Rev. E. P. Roe, well known as the author of several popular works, called our attention to some strawberries of his own raising which surpass, in the combined qualities of size and sweetness, any it has been our good fortune to test. The "Monarch of the West" was the name of the variety. The vines are very prolific of fruit, the berries hanging in thick clusters of every shade of maturity, and promising to last till late in the season. Even those which were not quite ripe were sweeter and higher flavored than we have been accustomed to find the ripe specimens of other rarieties which attain the same size. - New York Evening Post. 
Rev. E. P. Roe, of Cornwall-on-the-Hudson, has exhibited specimens of the "Monarch of the West" strawberries, which he has raised upon his place from vines less than a year old. They are fully an inch in diameter, of a fine red color, very fragrant in smell, and very delicious to the taste. Mr. Roe states that they are the most readily cultivated of any variety which he has ever raised, and they can be raised wherever a weed will grow. Charles Downing, who visited his place on Saturday, June 19th, pronounces the "Monarch of the West" the finest of about twenty varieties inspected, not excepting that which goes by his name; though $\mathrm{Mr}$. Roe himself thinks the "Charles Downing" variety the superior of the two.-New York Tribune.

Giants in These DAYs.-Mr. E. P. Roe, whose " Play and Profit in my Garden" our readers will remember, sent us last week some tangible evidences that he had not exaggerated its profits, however much he may have depreciated his own labors. Half a dozen baskets of strawberries were placed on our table, with scarcely a single fruit which one would care to take in a single mouthful. One, a "Monarch of the West," measured seven inches in circumference. The flavor of some of the varieties was as noteworthy as the size. The "Monarch" is sweet as well as large, though our favorite is a medium sized berry, the "Charles Downing." Mr. Roe has moved his garden from Highland Falls to Cornwall, and increased it from three to twenty-three acres. He has acres in strawberries alone and sends his plants as far West as the Pacific Coast._Illustrated Christian Weekly, written by the editor, Rev. Lyman Abbott.

I have tried to make the chapter on the marketing of small fruits of special and practical value, having spent considęrable time among the leading commission men in New York, and the retail dealers on Broadway and the avenues, endeavoring to learn from them the best and most profitable methods of shipping fruit. I have taken especial pains to get the views of the retail dealers as they come directly in contact with the consumers and therefore know which packages sell the best and best preserve the fruit. They also know what varieties of fruit give the most satisfaction. There are so many patented baskets, cups, bowls and boxes pressed upon the public that one is bewildered in his choice. The question can best be decided not by the enthusiastic puffs of the patentees, but by the verdict of the market. If 
it is a fact, that fruit "carries" better and "stands up " longer in one package than another-if baskets of a certain size and pattern find more favor with consumers and bring better prices, the information has a cash value to us all. I shall not get myself into a hornet's nest by criticising any of the perfect (?) patents offered, but merely mention those toward which the weight of favorable opinion in the market inclines. If I can by these means bring the growers and consumers into more direct communication, it would seem that I could scarcely fail in serving both.

Should this little venture meet with success, I may add a supplement from year to year, giving the results of my own, and the experiments of others, during the twelve months, and the conclusions of my own observation and the opinions of practical fruit-growers concerning the new varieties that are competing for public favor; a correspondence from Maine to California will preserve this judgment from a merely local coloring.

I hope my little manual will lead many more into the garden. It is a good place to be, or man-and woman also-would not have been placed there in their first perfect condition.

Wishing you nothing worse than ripe luscious berries three times a day for the three summer months I remain:

Yours in the bonds of the ancient and

Honorable guild of gardening,

E. P. ROE.

CoRnWALl-ON-THE-Hudson, N. Y. 


\section{S T R A W B E R R I ES.}

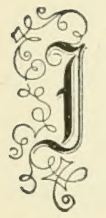

SHALL commence with that fruit which comes earliest and which nature thought fit to be the companion of the rose. That so many live without berries throughout the year-that such multitudes raise coarse weeds when a few hills of "Monarch of the West" strawberries would not take half the room nor be half as exhaustive to the soil, is one of the proofs of our fallen nature. Are not those who look carefully after their pork and potatoes but contemptuously ignore strawberries, totally depraved? There are some men who would never have been content in Eden until they had turned the better part of it into a cabbage patch. Such people need physical etherealizing by fruit diet that their grossness may be refined away. Rest assured, in Millennial gardens the cabbage will not crowd out the strawberry.

There is another class whose seared consciences I would like to touch. They believe in small fruits and know their value. They enjoy them amazingly at a friend's table; they even buy some when they are cheap, and may indulge in a forlorn weedy strawberry bed. But as to putting forth a little intelligent effort and supplying themselves abundantly - the time passes and this is never done. Why? I don't know. There are some who seldom kiss their children, read their Bibles, listen to the birds or look at flowers, although they believe in all these things fully. They simply jog on to-day as they did yesterday, ever vaguely meaning at some time or other "to live up to their privileges." 
But like their newlected strawerry bers they usually go on firom bad to worse till they have to be "turned under."

Remember, my friend-you who ocasionally smack your lips over a chance strawbery, if you have not a productive bed of your own (having place for one ) you are "siming against light."

In a city not a hundred miles from my limm there are many abodes of wealth with spacious gromuls in which in many instances, I am told, no place is found for the strawberry bed. "It is cheaper and easier to buy them," it is said. This is thrift with a vengeance. No economy in brass buttons and livery, but a little trouble (I doubt about the money) saved on the choicest luxury of the year. The irlea of going out of their rural parmlises to buy half-stale fruit! But this class is largely at the merey of the "hired man," or his more disagreeable derelopment, the "professed" gardener who gives his soul to rare plants, artichokes, and clipped lawns, but stints the family in all things save his impudence. If he tells his obsequious employers that it is cheaper and easier to buy their strawberries than raise them, of course there is naught to do but go to the market and pick up what they can. A true gardener like Mr. Thos. Skene, would send to the house a heaped basket twice a day for five weeks and if he had glass, for five months.

I congratulate those who have got so far back toward man's first happy state as to make the raising of delicious fruits their daily work. But as the conditions of life have changed somewhat from that primitive and perfect state, and dress and many other costiy essentials require money, I shall endeavor to show how every strawberry plant may be a source of profit as well as pleasure.

In conclusion, I would suggest to that small class (?) who enjoy making others happy that there are few ways in which they can succed better at home, and among their friends, tham hy supplying them often with the "finest fruit God ever made."

I trust that we are now ready to go to work, and the first things to be considered are, 


\section{Soil and Situation.}

Trit success depends very largely upon the character of the soil is a well established fict. Especially must this truth be taken into consideration in our estimates of the different varieties. This truth is most clearly stated by the enlitor of the American Agriculturist. In August 187.5 he writes-" $A l l$ talk about strawberries must be with reference to particular soils. As an illustration of this, the Rev. E. P. Roe exhibited in our office windows several successive lots of the 'Monarch of the West,' which were immense as to size and wonderful as to productiveness. This same 'Nonareh' 'behaved in so unkingly a manner on our gromels (very light and sandy in their mature) that he would have been deposed had we not seen Mr. Roe's berries, for it was quite inferior to either 'Charles Downing,' 'Seth Boyden,' or 'Kentucky.'"

In Southern New Jersey I have seen the 'Monarch' bearing finely in sand. I have succeeded well with it on both gravelly knolls and moist loam, and last season picked many berries that were five and six inches in circumference. I believe that few varieties are better adapted to all conditions than this berry, and yet the principle holds good that diversity in soil and climate causes great differences in the product of the same kinds. This is true of every fruit, the strawberry varying more than any other. $\Lambda$ fitrorite apple or pear in one locality is almost worthless in another. The true way is to test upon your soil the fromising kinds and learn which you can grow with the greatest profit.

There are many places like my own upon which there is a variety of soil. I have sandy loam, stiff, cold clay, gravelly knolls, and black, low alluvial land. Upon such a place one ought to be able to raise all varieties worth cultivation with fair success.

The soil adapted to the greatest number of kinds is a deep. noist sandy loam. airy and open in its situation. 'Those who 
have such level plots or valleys, where the moisture never fails, can produce enormous crops at little expense. Do not mistake wet for moist land. Where the water stands and stagnates on or just below the surface, the strawberry will not thrive. But a lithle dramage may comvert these low, som lamds into the most productive.

While the above named soils and situations are no doubt the hest, there are many excellent kinds that can be grown profitably on nearly all soils with a moderate cutlay in prepraration and culture. I have had fine fiuit on dry knolls that were thought almost barren, and some of the choicest kinds will flourish on a stiff clay.

Aroid shade. Many wonder at their half-barren beds and short fruit sason when the eround is exhausted of fertility and moisture by the roots of oversharlowing trees.

Choice of soil and expostre is one of the best and readiest methods of prolonging the suason. I have had ripe berries from early kinds on a warm sunny slope the 31st of May, and fine limit the midule of July from late varieties on a cold and northern exposure.

To the extreme north, warm land and sheltered situations should no doubt be chosen, but in our latitude and farther south it should ever be our aim to escape that hardness and thyness of soil which ent short the crops and hopes of so many cultivators.

Inving located our strawbery plantations, we next consider:

\section{The Preparation of the Soil and the best}

\section{Fertilizers.}

THe number of berries that we pick does not, usually, depend upon the area planted, but upon the preparation and enriching of the soil and the after culture. In most instances one

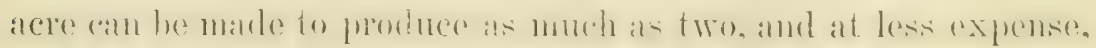

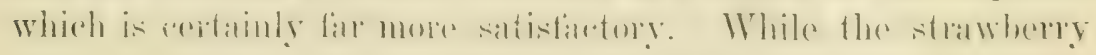
plant will live moder almost any circumstances, let it be most. 
clearly understood that large erops are only secured from a deep, rich, mellow soil. The ground must be thoroughly loosened and pulverizol at least a foot, and if possible eighteen inches in depth.

I have seen a man ligging over a garden plot with a short fork. The gromed was not stirred lower than six inches. No wonder that strawherries left to the mercies of the "hired man" wwally hear so poorly. If there comes a hot dry time as they are begimning to fruit, they often wilt to the ground. The fruit becomes hard and dry and late blossoms and young berries never mature.

For garden culture, cover the ground at least three inches with the finest and oldest manure that can be had, and then plow mal cross-plow. or trench with a spade to the depth of eighteen inches, or at least one foot. If you cannot get old rotten barnyard mamure, take the best you can; any fertilizer, with the exception of lime, is better than none at all. After making the ground smooth the garden plot is ready for the plants.

Does any one object that such deep stirring and enriching of the soil costs time and money. Of course it does, but the return is fifty per cent profit, while it is doubtful whether the old slovenly method would yield legal interest.

But let us say here that the soil must never be worked when it is too wet. If it erumbles under the spade or plow, it is in proper comlition. If it is sticky and turns up shiny from the plow-share wait till the sun, wind, or drainage have performed their offices.

In field culture, land from which a crop of corn or potatoes has been taken is in a proper condition to prepare at once for strawberries. If full of stones, clear it as far as possible, as they are unsightly and prevent thorough cultivation. Cart on manure till the gromed is thoronghly corered. Though this advice maly not apply to Western prairies, at the east and south we rarely err in over-enriching our ground. Turn all umler with a heary plow, followed if possible with a subsoil plow. Piek off the stones again if there are any, and cross-plow as deeply as possihle. harrow and pick what stones are left and you are ready for the 
plants. It is better not to mark out for them with a light cornplow till just before planting, so that the roots may be placed at once in fresh, moist soil. I think there are but few pratical fruit-growers who will not say that one acre prepared in this manner will yield as much as two run hastily over once with a jlow and harrow and then planted with little or no manure.

This thorough preparation gives not only a large crop, but also large showy fruit and a long season in picking, and here is where the profit comes in. Besides if the gromol is rich it resists drouth far better than if poor. Many of the berries sent to New York are so inferior that they scarcely pay the expense of picking, freight, and commission, and those who were economical of time and manure, or ambitious to count a large number of acres in fruit, learn by costly experience that only well prepared and cultivated land returns satisfictory profit. Let no one who has read of unusual yielils imagine that he has only to half plow an acre of rough poor land to secure like results. The conditions of success are simple but they must be complied with. Nature is not to be cheated nor "cornered." She ever demands square, straightforward dealing, or quietly checkmates.

If the land is in fair condition for corn, enrich it with from 30 to 50 tons of barnyard manure to the acre; if it is poor or comparatively so, do not be afraid to put on 75 tons. Mix this thoroughly in the soil by plowing and cross-plowing. If . manure cannot be had, guano, bone dust, hen droppings can be harrowed in at the rate of 800 to 1,000 pounds to the acre; though I would much prefer composting these concentrated agents with fifty times their weight of leaves, muck, sod, or even good earth. A pig-sty properly managed will emich a large strawherry bed, and I find my pigs, in working over weeds, leaves, and rubbish into strong manme, are worth more to me than their pork. A crop or two of green clover or buckwheat plowed under is most excellent.

But suppose the land designed for strawberries is in stiff sorl. In this case there must be patience and one makes haste slowly. A year, or at least several months, must intervene before the 
eroumd am be suitably preparest. In the first place there must he time for the sorl to deaty thoroughly, or else there an be no derpl plowing and ream rulture. The grass and weerls will be almost sure to master the strawberies. But in sod land there is monally another memy eren more fatal than half-sublued grass and weeds-an ugly customer with the portentous name of Phyllophaga Quereint. The name is bat enough, but the thing itself is much worse. You-need not draw a breath of relief, when I tell you that I mean only the white grub, the larva of the May-beetle that so disturbs our slumbers in early summer by its sonorous hum and aimless bumpings against the wall till it falls flown back of the bed and then commences to crawl till our flesh is rearly to reep also. 'This white grub, which the farmers often call the potato worm, is the most formidable foe the strawberry has, and often makes a clean sweep of them by the acre. There is scarcely any remely. The only way is to prevent, and this methor is directly in faror of a larger ultimate success with strawherries. P'ut sod land in corn, potatoes, or any hoed crop for a year, and if you letect traces of the white grub, for two years, and stir the soil as often as possible. Our Phyl-etc. beetle seldom lays its egres in plowed ground, preferring grass land where the larva will be protected from the birds.

But if one is in haste for strawberries he may set them out in Aurust or September after some early crop which has stirred the soil well. But if the fllow turns up the white grub we advise wating at least till the following spring, stirring the gromul several times and plowing deeply just hefore freezing weather. I had the good fortune this year to be able to plow, on the sil and the of Janulary, al piece of land infested with the grub. On the niwht of the the the gromm froze solid am therefore I think that alter a crop of early potatoes I can set out strawherries by the 1st of August, and thus get a fair cropl in June, 1S7T. But if i fuml Mr. Phyl- and limily in the ground rearly to commence operations, I shall snspend mine, for I have learned from sald experience that he and his can eat off the roots of plantis faster than I can put them out. 
In order to have a supply of plants, it seemed necessary for me to occupy some land that had been in sod the year before. As this sol was very linht and the soil firee from roots ambl weeds, I was able to subdue it sufficiently by fill-plowing. IBut I could not so briefly subdue the white grub, and every day last summer fonnd scores of plants wilting. On taking hold of them I would find every root eaten off, while an inch or more beneath the surfirce, peacefully reposing, was the gorged destroyer. Of course you ean vent your vengeance on a few, but as to killing them all. in land where they abound, I would refer the reader to Mr. Dudley Warner's experience with "pusley."

This chief, and it might be adderl, only formidable, enemy of the strawbery, may be found in limited numbers in old gardens and where every precaution has been taken. When the plants are valuable it is best to dig the grubs out, and usmally they are just below the surface early in the morning.

If it should so happen that one had bought a new place which was all in grass and wished to have a strawberry bed as soon as possible, I would advise trenching, and burying the sod, inverted, in the trenches, at least a foot deep. At that depth it would never grow and would make an excellent fertilizer. Then after enrehing the surfice he can set out plants and take his chances with the aforenamed grub.

But as a general rule let sod land have one or two years of thorough antivation before planting it with strawherries.

\section{Treatment of Different Soils and their Best Fertilizers.}

T'rne practical grower soon finds that different soils require diverse treatment. For instance, suppose one's land is of a light dry, simly, or eravelly nature. It would be great folly to treat this as one would stiff clay. Here we should use cooling manures and add vegetable matter as fast as possible.

The cleanings of the courstable are by far the best, and if horse-manure is nsed it should be composted and rotted with 
day, muck or leares. Rotted sods and leaves over which have been thrown sorlp-suits and slops from the house make an excellent compost and are greatly improved by the addition of woodashes. Indeed I think that there are but few sandy and cravelly knolls so dry and sterile but that a compost of leaves and wood-itshes alone scattered thickly over the surface so as to leach down with every rain, would make them profitably proluctive. Leaves are the natural fertilizer and mulch of the strawberry, and enough go to waste every year to make fertile every bed in the country. All light and heating manures tend to increase the natural dryness and lightness of the soil, whereas the constant aim should be to counteract this by adding the absent element of vegetable mould.

Now let us consider the other extreme, a cold, stiff clay that may even be inclined to wetness and sourness. This opposite kind of soil requires directly opposite treatment. Here light and heating manures are the best, and, in preparing the ground, may be carterl directly from the horse-stable and plowed in. The tendency of this land is to bake, crack and grow very hard. If a compost, well decayed, of stable manure, leaves, etc., is spread and left upon the surface, it obviates this and keeps the soil mellow and porous. Plowing such land into ridges in November for the action of the winter frost is very beneficial.

But if the water occasionally stands upon, or two or three feet below the surface, there can be no certain success without thorough drainage. I have been doing a great deal of this during the present open winter and ean recommend the "boxdrain" where stones are plenty. My men build two rough-ficed walls a foot high and a foot apart, and cover with large flat stones, chinking in carefully with small ones so that no earth can fimd its way into the drain as the ditch is filled again. This leaves a water-course a foot in the clear. Where there is not much water, the same form of drain of half the size will answer. This kind of stone-work is done rapidly, as two men in two short winter day's built thirteen rods with a water-course six inches square. 
Another rough cheap drain, when the flow of water is not great, is to set two stones upon the edyes and lean them together, forming a kind of an areh, and then fill up with stones around and over them. 'This can be done rapidly and answers very well. Then stone is not at hand tile no doubt will answer equally well.

We have thus given a considerable space to the preparation and enriching of the soil. This is the fomdation of all certain success and here is just where the majority fail.

Inaving thoroughly prepared and drained the land, the next consideration is,

\section{When to Plant.}

Tre strawberry is so tenacious of life that it may be transflanter with care at almost any season; but there are times which are especially lavoruble. In northern latitudes spring uniloubtedly is preferable. while at the far south October and November are the best months.

In spring, the gromol is moist, shower's usually abundant, and the impulse of growth is strong. At this cool season, the plants do not heat, or dry out during transportation, if packed with ordinary care. Land that is to be set with strawberries in spring should be thoroughy prepared the fall before, if possible. Noremher plowing is especially bencficial where the ground is inclined to be at all wet or heary.

The earlier they are plinterl the hetter. I make it a rule to set them ont as soon as the gromul is dry enough to work. Of comrse this term early is relative. and also depends upon the seasom. In 1875 little could be done in the open ground before May, and yet in other years I have had excellent success with plints set ont in March. Februny is a spring month at the far sonth, and April a winter month in hivh latitules. The safe rule in every region is to plant as soon as possible after the ground is dry enomeht. Throre is much to be satil also in favor of summer 
and fill. Plants set out in July and August, if kept liom rummers. produce a fair erop of extra fine fruit the season following, whereas plants set in spring should not be permitter to bear at all. Thus, much time is gained by summer planting. The followins: testimonials were secured by a bed of Monarehs of the IVest that I set out in August.

"I never saw such large berries in this country."-M[r. BaLL, of Ball, Black \& Co., New York City.

"Only in Scotland have I seen larger berries."-Rev. Dr. J. Forsyth, Chaplain West Point Military Academy.

"I certainly never saw so many strawberries growing together of such at uniform monstrous size."-Hon. JoHx BigeLow, Sec'y of State.

Plantings made in September and even October often yicld some good firuit the seatson following. Lamb on which an early crop has matured, instead of being left as a seed bed for weols. can often be plinter with strawherries to great arkantage in July, August, or September. In our latitule plants set out even in November, if they survive the winter, stant with wonlerfinl vigor and make a much stronger growth than if plinted in spring. I once set a bed of Charles Downings in Norember. Two-thirts of them died, but the few remaining soon male up the loss and coveres the ground. Some prefer October and November for setting, and protect the plants by drawing a comple of inches of earth unom them just before winter and then moover early the following sming. I have not tried this to any extent but know a gentleman who suecechis with this method on a stiff clay.

'The chief difficulty in summer planting is the drouth and heat usmal at that season. If there comes a showery time, ats is often the case, this obstarle is removed. I set out a large numher list summer and lost a far smaller per cent. than in the spring, which was dry. If one has plants upon his own place, and can take them up with a ball of earth around the roots. and water after setting, they will searcely show they have been moverl. Eren plints comme from a long distance can be saved hy some extrat cane. I sent arvay thomsambs and chiefly 
by mail, all through August and September last year and there were only a few complaints of losses. I expect to put out two acres next July or August.

Still, as a general rule and for large plantings, experience proves that it is safer to set out strawberries in spring.

\section{Obtaining Plants.}

If you have them, or can get from a neighbor just what you want. this is a simple matter. But there are multitudes who, like myself, in starting a new place and getting new varieties, must purchase at a distince. I find that sending to trustworthy dealers and paying a fitir price, is by fur the most profitable course. Some have a mania for getting everything cheaply, although they like to ohtain good prices themselves. They quote to the regular dealer some very low terms that they have seen or heard of and ask to be supplierl at the same rates.

There is a large class who cultivate a few of the leading varieties by the acre for their fruit. In the spring they must thin out their plantations to keep them in bearing condition, and are willing to sell the surplus, - and I might almost say refuse-at the time for anything they an get. But to make the low prices for this transient supply the standard for the regular plant-grower who at great labor and expense keeps pure and separate a large and varied stock, and is rearly to fill an orter at any time in the season, is both mujust and absurd. In buying new stock I go to men who have won a reputation and whose prosperity depends upon their keeping it - who will honestly try to sell me just what I ask for and believe that they are doing so.

I have heard of agents and transient men buying a large number of plants of a single kind and then filling all their order's from this one lot, jutting on labels of different varieties to suit their customers. 'The established firterrower, even if he is not a gentleman, camnot afford any such trickery. Of course mistakes are made by the most careful, but they are mistakes and 
not something else. Hren thomeh we do om lrat. trouble often arises. It is rely easy to say that ones plants are pure, but not so easy to be sure of it until after they have fruited.

'Though you huy your stock from the most trustworthy growers, through somo mistake, or the carelessness of a workman. another kind is sent and put unsurpectingly among pure plants. or a few plants ly some chance are tied up where they do not belong. You think your plants are pure but find as they comm into bearing that they are mixed. I have so trained my eye, that I recognize the fruit and foliawe of the learling linds instantly, and if a plant even looks suspicious I now dig it wp and throw it away, as I do also plants that produce pool and imperfect berries. I have more and more fiath in careful selection, and in propagating from superior stock, and shall take special pains to carry out this principle on my new place. I wish to be able to say of my stock, I know it is pure.

Do not be deterred by ristance from sending for what you want. There hut a few hmolied plants are desired for home use the mail offers great ficilities. In 187.5 I sent more than 32,000) strawbery plants thomgh the mails in addition to those forwardel by expless, and there was but little complaint and loss even during hot weather.

()f course large orders and bulky kinds of plants must go by express or freight.

\section{What kinds to Plant.}

Turs is a question mpon which few will agres and I do not hope for a rencral entursement. But I shall give the best light on the subject I can. sugresting that the grower must leam largely by experienes what linels he can raise most profitably upon his soil and in his lomelity and with reference to his market. For the main crop I would andrise that half or two-thirels of one's laml he sot mi wit? Milsmis Alhany seofling. This variefy 
is the strawberry wheat ami will always sell at some price. There are but few regions where it cammot be grown frofitahly. and it certainly is the most abumbant bearer of any variety yet generally known. On strong moist land it will produce enormous crops of fair sized berries. But if the gromel is poor and becomes hard and dry during the bearing scason the fruit runs very small toward the last, and scarcely pays for picking.

After the main planting of the Wilson, there are a dozen good varieties to choose firm, and which of these are the most profitable will depend largely upon the nature of the soil, locality and market. If the soil is a good moist loam or incliner to clily, I would recommend 'Triomphe de Gand, Jucunda and President Wilder, grown in narrow rows. These rarieties always bring high prices, but on light land and with ordinary culture selilom pay. On a thin sandy soil I would sugrest Seth Boyren, Monareh of the West, Charles Downing, Kentucky Seedling, and Champion, arding that these strong growing varieties with ordinary care will grow and hear well on almost any soil. The Downer and Green Prolific flomish where a weed will, and few weerls can get the better of them. They bear abundantly berries that are tolerable for home use but too soft for market. They are goon varieties for those who want strawherries without labor. On the other hand, for the amatern who is willing to pet his plants and keep all rumer's eut, the La Comstant, lemigrs White, Black Defiance, and Kissena give beautiful and delicions firut. There are also new varieties of great promise, the best of which to my knowledge are the Star of the Wrat and Kerr's Prolifie seerlling. One of the larerest. Hhe latest and most beantiful berry that I have seen is the Pres. Wilder. 'To my taste its flavor is momprassed and it also hrings the highest prices. It hears well with me, but requires a strong, moist. rich soil. It s! hould havea place in every garden. For general culture after the Wilson

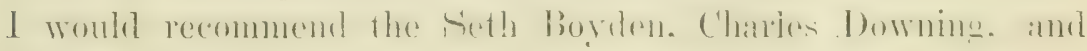
Monarch of the West. I would also advise the trial of several

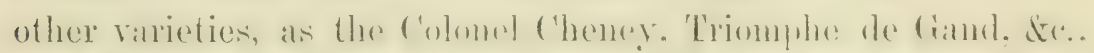
on a linited scale. The gerower must learn ly experience what 
kinds he can raise with profit, for soil and locality cause more differences in the strawberry than in any other fruit. In some markets quantity is the main thing, but in New York fine quality and size secure the largest returns; I therefore am planting chiefly the large varieties. In order to have a long strawberry season, plant on a warm southern slope the Nicanor, Black Defiance, Wilson, and Triomphe, or other early kinds. The leading varieties that I have named will come in as the main crop. For late fruit select a moist soil with a cool northern exposure where the snow melts late, and set out President Wilder, Kentucky, Jucunda and Triomphe de Gand. While the last is early, it also continues late, remaining in bearing longer, if kept free from rumers, than any other kind with which I an acquainted. New rarieties may enable us to extend the season still more. The monthly Alpines will bear till frost, and in rich moist soil give considerable fruit in the fall.

I am more and more inclined to believe that even those varieties that bear perfect flowers, $i$. e, both stamens and pistils, are rendered increasingly productive by growing near each other, so that the pollen, during the season of bloom, passes freely across the different beds with every breeze and is carried from one blossom to another by the honey-gathering bees. While I keep my beds far enough apart to prevent all intermixture by their rumning together I think that I get better crojs by growing several varieties as neighbors.

\section{How to Plant.}

In the moist season of spring this is usually a simple matter, and careless work succeeds. And yet there is a difference between plants merely living and having them stirt at once into vigorous growth. Skill and care alwalys pay, though they are not always necessary.

In the spring take a handful of plants, stretch out the roots straight and shorten them by entting off at least one-third of their length. Where plants are bought, they often come tied in 
bundles of fifty, ant the work of cutting off the ends of the roots can be done readily with a sharl knife. Set out if possible on a still day. A cold dry wind is far worse than the mild ratiance of an April or May sun. In any case the roots must be kept moist by moss or water till they are in the ground--the ronts, not the tops. Many leave their plants in water till the life is soiked out of them. Do not plant when the ground is wet and sticky, unless thring or just hefore a rain. If the sun and wind strike wet gromel immediately after it has been stirred it often becomes like harl mortar. In the spring. and especially in summer and fitl it is better to set plants soon after the preprirattion of the soil, before even the surfice has time to dry. In the field harrow the land smooth, use a line if possible, or let some one mark out with. a plow who is not like a man that once workel for us and planted corn so crooked that the crows could not find it. Let the rows for field culture be three feet anart and the plants stand one foot from each other in the row. At this distance 14,520 will be required for an acre. Spreal the roots ont as fir as possible and put them down their full depth but do not cover the crown of the plants. Press the gromel firmly around the roots. Millions of plants are lost by loose, "areless setting.

In the girrlen where the plow will not be used the rows mily be two feet a part insteal of three and the plants one foot alpart in the row. Or berls four fecet wille can be mate with a walk of two feet between them. Put three rows down each bed, planting the first six inches from the walk and the other two rows eighteen inches a part. If plants are scarce or high, they can be set three feet alpart in the row and each one permitted to make two new plunts which can, be caused to take root in the row so as to leave rach one a foot apart. which I think is the hest distance. But to be sure of a good strong bearing bed the following season it is not safe to set the plants less than one foot alpart in the row.

Even in spring, unless the gromul is rery moist and the time showery, it is well to gire the plants a good sprinkling. If it is at all dry and hot, watce thoroughly, and after the water has 
soaked away, draw a little dry earth over the wet surface to prevent its baking and to retain the moisture.

In summer and fall planting there will be no trouble if we ean hit upon a showery time. But it is not always convenient or possible to wat. If we are setting out plants from our own place, it can readily be done. exrept in a severe drouth, by taking them up with a ball of earth around the roots. Use a carrlen trowel or sparle, cutting down on fom sides so that the soil will not crumble away from the roots. With a hand barrow, or some boarts nailed across two poles, a couple of men can take up a hundred or more at a time, and carry them without jurring to the bed where, holes having been prepared before, they can be put at once into their places. In this way I have set out large beds in the heat and drouth of August, scarcely losing a plant, and expect to set two acres next summer after taking ofl a crop of early potatoes. Of course the plants so removed need one or two liberal waterings and then dry earth drawn up around them the next morning. It should be done in the cool of the afternoon or upon a clouly day. A few rows can be set out every cvening, preparing the ground just before, so that it may be moist and fresh.

The same result can be secured with even greater certainty by another method. In most country homes there are small flower-pots lying idle during the summer, or it will pay to buy a hundred or more four inch pots. These can be sunk in the earth so that the rims are just below the surface along the rows from which new plants are desired, and the rumners so guided that they will take root in the pots. If this is done the midille of July, by the first of August you will have strong plants that ean be set out in beds to fruit the next year and the pots used in the same way again. From many growers potted plants can be bought in Angust, and unless trented with utter neglect are sure to grow. Plants set out by either of the above methods in summer or early in fall yield a fine crop of splentid berries the season following.

But ordered plants often come by mil or express in hot dry 
weither and there is no earth around their ronts to give them an

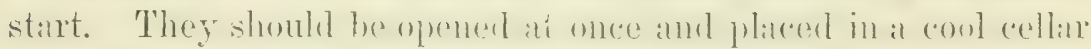
with damp moss around the roots, or the roots buried in some moist shady place till evening. In the aftemoon prepare the gromul so that it maty he fresh, and ats sem ats the sum is off "ommence setting. If the roots look at all black shorten them onethird as in spring, in order to stimulate a new growth. Otherwise we do not shorten roots in summer and fall. Mix good, fine garden soil with water till a sticky paste is mate that will coat the roots as you dip them inte it, then put them down their full depth in the moist soil. sprealing them as far as it can he done, and press the gromul ing firmly about them. Water thoroughly, soak the gromel and then draw over the wet surfice dry earth. It is well to shate them for a few days hy liarge inverted flower-pots, boards, shingles, old strawberry bitkets, etc. A mulch of eut grass or litter of ans lind that serves to keep the gromed moist, is of value. I hatre had excellent success on a large scale by throwing a hatudful of coarse weeds on the top of each plint, being sure to remore them by five r. u. each day, and putting them back in the morning, continumg the protection till the plants stant to grow. Then the danger is orer unless it should be rery dry, in which are the ground around fhem must be kept moist till rain comes. By the liberal use of mulch, this can be done quite easily.

With late fall plantinges, as in spring, there is little dinger from drouth and heat, lout the plints often do not become sulficiently established to stand the winter.

I would sugest the general trial of the experiment of corering late plantings with two inches of earth in Norember or December accorling to latitule and then uncorering early in spring. 'Time and labor is abmelant in the fill and phants which can he marle to survive the winter start with ahmost domble rigor in the sprimg.

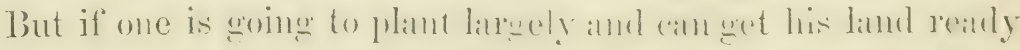
the work can be more easily and wallely pertorned in spring than any other time.

Having set out our plants we next consider 


\section{Modes of Culture.}

As a general thing our after treatment will depend upon our olject-fruit or plants. With me a rapid increase of plants is the chief object from most of my beds. All I have to do in this case is to make the ground very rich, keep out the weeds and let them run, which they will generally do fast enough. They can be greatly aider in rooting however by keeping the surface loose and by top dressing with fine rich compost in July and August. Even those not rooted in October will make good plants by spring if the ground is well top-dressed, seattering the fine manure broadcast over the plants. When the variety is valuable I have them layered by pressing the young plant into the soil and drawing a little earth over it. But while raising plants is simple enough it is even more expensive to cultivate for fruit as the ground between the rows cammot be kept clean by mulch nor the cultivator, but must be weederl out in large areas by hand. Where plints are the object the land can scarcely be made too rich, and a top-dressing of wood-ashes and a compost of hen-manure and fine earth in the spring and just before rains during the summer, are great stimulants. Where these camnot be had, guano and bonedust are excellent. But these strong concentrated manures must be used with care or they will burn the plants like fire. It is usually best to mix them with ten times their bulk of earth or muck, and scatter the compost around, very near, but not on the vines.

I shall keep my beds free from old plants by stretching a line along the old rows about the 1st of September and spading them deeply under. After strawberries have been grown upon a piece of land about four years I shall turn all under as soon as they are done bearing and sow buckwheat and plow this under as it comes into flower. The following spring I shall plant potatoes, corn or a root crop. And after the land has hal the rest of change plant again in strawberies. Raspberries or any other of the small fruits can be planted with advantage on ground that has been in strawberries. 
With the majority, howerer, strawherries are raised solely for the sake of their fruit. As a general thing it requires consideritble time, and extensive and therefore expensive advertising to build up a profitable business in plants.

What is the best method of culture where fruit is the chief olject? I will briefly give that one which most pleases me, and then mame some others which may be better and more satisfactory to the grower.

For the field I prefer that the rows be three feet apart, and the plants one foot apart in the row. If set out in spring, keep the plow, cultivator and hoe going among them so that the ground is always loose and fiee of weeds. Let no rumers grow. If you want new plants of the variety, set out a bed for the purpose and let them corer the ground. There is no such excessive labor in keeping off the rumners as many suppose. $\Lambda$ little boy or girl with a pair of shears, by going over the platnts once a week, in the rumning season, will keep a very litrge area free. When there are children in the family, the work is so light as to be almost play; and if they are paid something, the satisfaction of earning money for themselves will change the task into a pleasure. Where many are grown it will pay well to hire one or two grood boys and they will keep acres clipped. There is no need of putting high-priced labor at the work. 'Thus the plants, whether set in spring or fall, are permitted to make no runners unless the varieties are rery scarce. Eren if they are, I keep a few hills or row clipped to see what they will do with good culture. It must soon become obvious to those who have studied the habits of most varieties of strawberries, that a plant will expenel most of its vitalify in its effort to propagate itself. If the best results in fruit are desired, this vitality must be restricted to the one office of producing berries.

By fall, plants treated in this way touch each other and make a strong, bushy, continuous row. Of comse if any of the plants die, I let enough rum to fill up the spaces. By having but a single line of plants the plow and cultivator an rum very elose to them the first year, thus keeping the ground mellow and 
moist and leaving hut litle hocing and handwork. Pick off all blosinns and permit no fruit to form the first year unless it be on

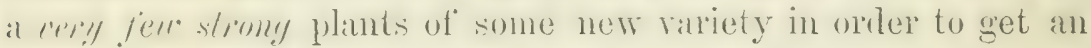
illea of the quality. As the gromm hegins to freeze, I cover the rows two inches deep with light strawy stable-manme, leares, or any conse litter, but never with strong wet manure. Erergreen boughs, where they an be ohtined with little trouble, make one of the best winter protections, and for a choice bed in the girrlen it is often well to take a little pains to procure them.

Ererly in the spring, befure the plants begin to grow to any extent, dig or plow the spatces between the rows. After the plants are in blossom they must not be disturbed, mless the gromul has been neglected and grown hard or weerly. In this (ase I believe it is better to loosen the soil with a small subsoil plow, fork, or long pointed hoe, get ont the weeds, and put on a mulch, or they will smother the arop; and if there comes a drouth, the fruit will be small amd almost worthless on hard, and therefore dry ground. But there should be no such neglect where people wish to succeed. Stir and clean the lind between the rows and full out all weeds as soon as the gromen is dry enough to work; then level it down and put on the mulch at once while it is moist and mellow. Leaves, marsh hay, especially oll deal grass from the rakings of the lawn, milke an excellent mulch. Enough litter is burnt every spring to double the strawberry crop. Having put the mulch on two or three inches deep so that weeds cammot grow through it, the plamts may be left till alter the picking season is over. The mulch serves a quadruple furpose, keeping the ground moist, the weeds from growing, the firtuit clean, and in wet weather enabling une to walk between the rows without miring or getting mudily. Berries that lie down in the mud and sand will not sell in any market, and for our own tables we prefer powlered sugar and cream to at mixtme of latin water and earth.

If before or churing the bearing season a few rampant weeds show themselves in the rows or elsewhere, they can be pulled out by hand. Do not hope to laise many sirawberries and many weeds on the simme groumd. Virtue will fire just about as well 
with rampant vice in the same heart. Both reeds and vices are fonsht best when they ane little. Mr. Dewning tohl mo of a man

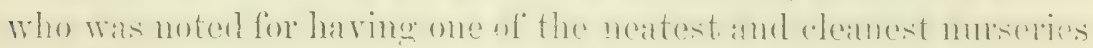
in the country. The secret of his success was that he kept

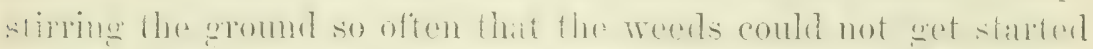
or establisher. At the same time he employed less help than others cultivating the same slate. If. an is often the case an gund wound and with some rarteties, the plants commenes rumbing in June. let the little boy commenere with his shears and continue to clip off all rumners as long as they form.

The mulch can be left between the rows, keeping the weeds from growing during the bus season. Shout the first of sentenher the mulch will be quite rotten and the weeds pushing through it. Now spade or plow it under and weed the rows out thoromghly. But the best results will be ohtamed by diguing the mulch unler as soon as the butring soason is orer and cultivating between the rows till the plants are again covered for winter. This turning moner the muld in of uly, Angust, or eren september, will so renew the plants that by winter they will he stronger than ever and give eren a better crop the onsume year. berls thorombly cleaned in Septemher will scarcely become weedy before winter and can wait till spring hefore another weeding. Thus with a heary mulch botween the rows, two thorongh cleaninge a yall will keep them in good contition in most carces. As the gromul begins to frecze give winter protection as before.

This treatment can be kept up from three to six years, according to the rariety. The Triomphe de Gand would continue productive even seven years, I think.

As som at the plants of any lind begin to fail, dig or plow all maler and make a new bed somewhere else. Do not keep a strawherry bed ten or fifteen rears in the sime platee, silymg will an atcpuantance of mine. "It is more convenient there than

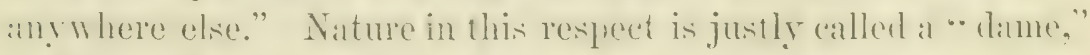
and here will is not to be trifled with. She hats a feminine love of variety and gets tired even of strawherries after a time. If mor ams. therchore, to fut his heds not merely where they are 
convenient, but where he will get fruit, he will move them around as often as posible and give the land the chimge of a different crop.

The " hill-system" is similar to the above only the plants are kept farther apart, so that in some eases the cultivator can go between them both ways. I lo not think, as a rule, any larger fruit is obtained by this method than from the natrow and contimuous row, and there are grave objections to it. It leaves too much space unoceupied. It is difficult to mulch these wide open spaces so as to keep the grouml moist. These mproductive spaces are apt to he widenesl by plants dying. In the single row system if a plant dies a rumer can be allowed to take root at once in its place.

What is termed the "annual system" has great advantages, especially where one has plenty of lamd and can shift his beds often. In this case the soil is made rery rich and the plants are put out in spring. The spaces between the rows are cultivated and kept clean until the rumers start strongly and then these are left to cover all the ground, which they will do by fall. On the approach of winter the entire surface is covered with marsh hay, leaves or strawy manure, the coarsest of which is raked off in spring and stacked for future use. Some employ straw cut into inch pieces which is left on the ground, the plants growing up through it. Pine leares or neerlles are an excellent mulch or winter protection. After the winter covering is taken off, paths " foot wide are cut through the beds for the pickers and the rest of the plints are left to fruit. Tmmerliately after bearing they are plowed under and the following year a crop of corn or potatoes is cultivated, and then the next spring the land is set with strawberries again. Thus only one crop is taken from a planting. 'This is found a very profitible way of cultivating certain varieties like the Hovey, Wilson, Charles Downing, ete. But it will not succeed well with the very large varieties like the Seth Boylen, Monarch, Jucmola, and Triomphe, ete. In land that is inclined to be very weedy and grassy or to become hard if not stirred and mulcherl, I fear these elosely matted beds would disappoint in hot, dry seasons. 
Mr. Wm. Parry, who is one of the most practical and successful horticulturists on a large suale, in New Jersey, gives the following as one of his favorite methods of culture :

"A plan that has given good satisfaction with me is to open furrows 2. feet alpart, and spread a preparation of erpual parts of marl, ashes and ground bone along the furrows, after it has been mixed and incorporated together for ten days or two weeks, until the heat, generated by the action of the ashes and marl, has mellowed and softened the bone so that the particles will crumble like chalk when rubbed between the thumb and fingers. Using one ton of the ground bone, and the same quantity each of ashes and marl, on five acres, will give a vigorous growth of dark green foliage to the strawberries.

"The ground being frequently stirred with horse and cultivator close to the rows, leaves but a small portion of the ridge between the plants to be loosened with the hoe. As the runners extend and widen the beds, the cultivator is made narrower; and carre being taken to pass along the alleys every time in the sime direction, drawing the rumers always in one way will leave them more even and regular tham if drawn both ways by going back and forth in the same alley. The plants then form ridges about 18 inchess wide with alleys one foot wide between them. This plan is more cortain and reliable than keeping the plants in hills and cutting off the runners. There is less hand labor, most of the enltivation being done by horse-power, and if some of the plints should be destroyed by grubs or insects, there will be enough left to produce a good crop of fruit.

" $\Lambda$ t the atproach of cold weather or beginning of winter give them a good coat of stable manure, spread evenly all over the plants. If the rows are 2.1 feet aprart, a horse and each cart wheel will follow along an alley without injuring the plant... The enering with manure is of great impurtume, als it protects the buts and embryo fruit from severe freezing. and prevents the roots from lifting and heaving out as the frost leaves the ground. The rains, soaking the strength of the mamure into the soil, give food and nourishment to the roots. 'The straw and coarser materials, being bleached and beaten clese to the ground by the winter's snow and rain, do not prevent the young growth from coming through in the spring, but serve to keep the fruit clean in summer."

I should regard this method as peculiarly adapted to Mr. l'arry's lant, which is a rery light, samly loam, in no danger of baking or becoming hard, and not greatly troubled with grass or white elover, I should judge.

But I think that in most localities the method first described 
il faithfully camion out will gire the most satisfaction and profit, especially in the garden.

As the cultivator grows in experience he will try methods of his own amb morlify others to suit himself. One mothod how-

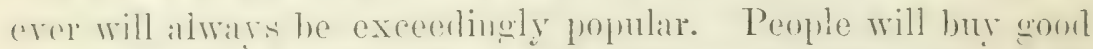
plants hut lot them stand around in the wind and sum or momliting in the cellar mutil mueh injured. Then they will set them

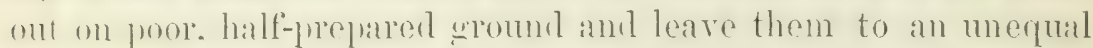
finh with was and weeds till picking time when the wretched rep will lead them to borate both the plant-alealer and strawhary culture as arrant humburs. They will then plow the lanli-choked plants under and return to their congenial crops of cabbage, corn, etc.

\section{Raising new Varieties.}

If one wishes to raise new varieties he can do so in a haphalzill way very easily. Select very fine herries of the different kimks which contain the qualities which are songht to be uniterc in a new variety and mash them into dry sand so that all moisture is alssorbed. Prepare a seed-bed of rich fine soil in a halfstady place, sow the mingled sand and seed at once and sift through a coul sieve fine rich earth upon them till they are corered one-fualter of an inch. Keep the seent-bed moist and in four weeks the little plants will begin to ajpear. On the approach of winter corer the young plants with one or two inches of straw. In the spring put them out eighteen inches apart each way and number them. Keep off all rumers. A few may bear the first year, hat you camnot tell much about them till the secomil. Then you can thin out your seedlings rery fist, for most of them will prove far inferior to those now in cultivation. A few may he pretty good. Two or three muy he excellent. One or two may possibly be first class, eren better than any thing known. But the probalsilities are that out of 1000 seedlings you will not get one ats gool an many varietics we now have. Raising new seedlings is an inmorent and nectul form of gambling in which blanks are 
innumerable. But to draw a prize like the Chas. Towning or Seth Boyden is a good thing for the whole country as well as for the fortunate possessor. Seedlings of promise should be taken ul) with a ball of earth and set by themselves where they can spread and be tested more fully. When in blossom note and mark carefully whether the flowers are pistillate or perfect. Flowers which possess both stamens and pistils and which fertilize themselves, producing fruit without the aid of another variety, are termed "perfect."

The mysteries of scientific hybridization and forcing under glass do not come within the seope of this practical hand-book. For these and kindred topies, the history of small-fruits, and full lists of rarieties, few of which are in general cultivation, I refer the reader to the valuable works of A. S. Fuller and others, which can be bought at the office of the American Agriculturist, 245 Broadway, New York.

At the close of this manual will be found a chapter on picking, preparing small-fruits for market, and the best packages for shipping.

\section{Varieties.}

I will close this chapter on strawherries with a description of some of the leading kinds that are now in favor.

Monarch of the Wests_-The largest of all; fruit enormous, and averaging large to the last. I picked one berry that measured 7 inches around, and others $6 \frac{1}{2}, 6$, and 5 inches. It is also the most vigorous grower I have seen. Though so large it has a very fine flaror and a delightful aroma. With me it has proved a good bearer on both light and heavy soil, and I have seen it loated with fiuit on the New Jersey sand. A superb variety for home use, hut a little soft I fear for distant markets. With a near market and with careful handling it will bring the highest prices.

Seth Boyden (No. 30), - This is still one of my elief faro rites. 'Though a comparatively new variety, its reputation is 
now established as one of the very finest. It certainly is the sweetest of all the large berries, and for home use cannot be surpassed. It scareely requires sugar, and yet is far from being insipid. It is one of the strongest growers and very hardy. With slight protection, it will stant the severest winters. Berries immensely large, very many under ordinary culture measuring four inches around, and some five. A good bearer. I have sold man! bushels in New Tork at 40 cents per quart, and they retailed at 50 cents. I have disposed of many thousand plants of this kind, and, though soil, locality and culture make a great difference with every variety, I am hearing from all quarters, golden opinions of the "Seth Boyden." A gentleman who has tested hmulreds of varieties, places it as second best on his long list, after a careful comparison in the fruiting season. He regards the "Monarch of the West" as the best on his santy soil. $\Lambda$ friend writes that he picked as many quarts of "Seth Boyden," from a half acre as from the same area of Wilson, kept carefully in hills, and ards that they carry excellently to market. I find that they "stand up" among the best. Many complain of the "green tip," but if they will only leave them till ripe, they will find no "green tip."

Charles Downing - One of the best varieties grown. Fruit linge and abundant. The more I see and hear of this kind the more I find in its favor. It is extremely vigorous, hardy and productive. It seems to do well on any soil, and is excellent for home use, but soft for distant markets.

President Wilder.-Locality seems to make great differences with this variety, but upon my soil I regarl it as one of the best. It is with me exceedingly large, quite prolific, and one of the very litest. It is the hamdsomest berry I have, and in color, shape, and flavor cammot be surpassed. It carries to market well and brings the highest prices. But in some localities I am told it does not do so well, and I have seen it looking poorly. It requires good soil and thorough culture. I like it better every year. 
Triomphe de Gand,-An old, well establisher favorite. If I were compelled to raise but one strawberry I would choose this variety, for the reason that it remains so long in bearing, and has also the gooul qualities of being large, firm, of a sweet, rich flaror, and a gool bearer. But it recunires high culture and the rumners well cut. A bed of Triomphes, well cared for, will last longer than any other kind I have known.

Champion. A very fmomising new variety. Fruit large, and of a spicy aeid flaror. Plants rery rigorous and exceedingly productive. I have fruiterl it and have seen large berls in bearing, and it bids fair to be one of the best. Season medium to late. It must be planted near other kiuds, as it will not bear alone. Last season's fruiting has greatly increased my confidence in this variety.

Wilson's Albany Seedling.--The most abundant bearer in existence. I have known single plants to produce over 400 herries. It is the great market berry, of medium size, firm, and very acid.

Jucunda $-\Lambda$ superb variety if you can obtain it pure and right, which I haive found considerable diffieulty in doing. I hatd a bed in full bearing this year, which I know to be pure, and a more beautiful sight I never saw in the way of strawberries. Fruit enormous, bright colored, and firm. It should have rich soil and runners cut.

Black Defiance,-A very litrge, dark colored, high flavorerl berry; excellent for home use. Too dark for market. Only moderately productive with me.

Lady of the Lake.-A very fine berry and worthy of a place in all collections.

Lenig's White $-\Lambda$ beantiful and delicious white berry with a pink blush. It is a strong grower and hardy, but should be kept rigorously in marrow rows. It is a shy beareer at best.

Late Prolificm-Neither late nor very prolifie with me. but 
well worth a place in an amateur's collection. Large, showy, and of a surightly acid flavor.

Matilda, - I large, showy berry, fruitful, vigorous in its growth, and like its parent the Jucumda requires a deep rich soil.

Colonel Cheney. -1 s a market berry this variety is coming into linvor, and is sail to be very large and handsome. I shall test it quite thoroughly this coming season. I know that it is a good gruwer. Its flowers are not sufficiently perfect to bear well alone and it is well to plant Wilsons on either side.

Kentucky,-One of the very best late strawberries, of bright showy color, a mollerate bearer. The flesh is pure white and of excelient flavor, and the fruit large.

Agriculturist.-Very large, irregular, with a long neck and inclined to be flat and coxcombed in shape. It does best on a light soil. With me it was prone to decay and scald. It is rather soft for market.

Nicanor - A medium to small, bright colored berry, very early-the earliest that I have seen, hardy and productive.

Downer's Prolific_-The lazy man's berry. Medium to larce, soft, acid, highly perfumed, early, hardy, and an enormous bearer.

Green Prolific - Another lazy man's strawberry, as it will grow where a weed will and prodnce plenty of fruit, such as it is, soft, acid, large, and of a pale crimson.

Dr. Warder - 1 large, long pointed berry, very firm, late, fine, but with me a moderate bearer.

Hovey,-1n oll variety and still much esteemed in some localities, especially near boston. It is large, conical, bright crimson, and of a good sprightly flavor. It will not bear by itself, as it is a pistillate variety.

Russell's Prolific - Very large, deep scarlet and of good quality, doing best on light land.

La Constant_- 1 beautiful and delicious berry, but requir- 
ing the richest soil and highest culture with runners cut. A fine fruit for the amateur.

The monthly bush Alpines, white and red, should also find a place in the garden, since upon rich, moist soil and with clean culture they will supply the table until frost.

If any enjoy a musky flavor let them cultivate a bed of Hautbois.

This is but a very partial list. There are humdreds of old varieties which in the main have gone out of favor. There are also scores of new ones, very few of which, notwithstanding the enthusiasm of the originators, will ever become established favorites. I shall test these new comers and report accurately on their behavior with me. The two most fromising new varieties with which I am acquainted are the following. The first is thus described by a trustworthy grower who has fruited it:

"The two Great Strawberries now raining attention are the Star of the West and the Moxarci of tine West. The latter has been fully described, and largely planted for market; one grower, after proving its good qualities, plinted ten acres.

"The Star of the West, more recently introducerl, is destined to rise far above the Monarch. It has large strong foliage of a dark green color, leaves moderately serrated, with strong fruitstalks, blossoms perfect, fruit uniformly large, measuring three to four inches in circumference, bright deep red, smooth, firm flesh of delicious quality; very productive, carries well and will be in great demand."

Kerr's Prolific.-This is the new variety upon which I promised a report in my spring circular, and I am glat to saly that it is fulfilling its rich promise. It is a very vigorous grower, hardy. exceedingly productive, fruit handsome, fine flavored, areraging large. Of its maket qualities I camot yet speak fully. That is a question which experience must settle. If it is firm enough it will be a first-class market berry. 'The editor of the IIome. Farm and Orchard silys of it:

"We have had the opportunity from generous samples to test 
the quality of this straberry, raised by Mr. Robert A. Kerr, and we do not expect to find a better flavoreal or finer berry."

We have enough merely goor berries. As the proverb goes, "There is always room at the top." If better varieties than we now have an be originated they will be most welcome. That any of the new and wourlerful kinds that are now being trumpeted over the land are better, can only be learned by a careful trial, reaching through a number of years and over a wide and varied region of country.

But we have no cause to complain, for the long list of good and very good varieties is like the bill of fare at a fashionable hotel of which a traveler complained that it would take him a week to eat his way through it.

They who live without strawberries, certainly miss one of the best things that this old, thorny, and thistle-cursed globe can produce. Man's folly gave the devil a chance to plant his hoof on Eden, but he was not permitter to stamp it all out of existence, and one of the daintiest little bits remaining is ripe with us about the tenth of June. 


\section{RAS P BERPIES.}

AM taking an increasing interest in this fruit, as the following, from the New York Evangelist, will suggest:"Our friend, Rev. E. P. Roe, has on exhibition at the office of the Americun Alfriculturist, 2tij Broanlway, seventeen distinct varieties of raspberies-IIerstine. Ifulson River Antwerp, Franconia. ILighland Mardy, Sammlers, Bedle de Palluan, Belle de Fontenay, Vice-President French. Clark, Old Purple Cane, Brandywine, Philadelphia, Mammoth Cluster, Doolittle, Davison's Thornless, an mknown variety. and a seedliny that promises to be exceedingly valuable, as it is as lareve amd firm as the Antwerp, and stood out last winter without protection."

Why families are without this delicions and easily raisert fruit is a mystery. It also promises to be increasingly profitable to those who are near grool markets. as from its softness those at a distance camnot compete. Pear's and grapes may be sent from California, but not raspberries.

The list of good raspberries is not by any means as long as that of strawberries; not that there are not a creat many varieties in the catalogues, and many new candidates for faror which are, as yet, grarded by the sangume proprietors as jealomsly as harem beauties, but there are but few of them which are known to be productive and vigorons, exeept in limited loealities, and under very favorable circumstances. There is still great room for im-

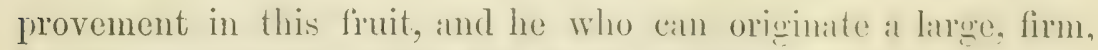
bright colored berry growing on hardy, productire, vighous canes, 
and ardapted to a wirle range of country, ought to greatly arlvance his own fortumes, and certainly will confer a benefit on the public at large.

The IIudson River Antwerp has been regarded as the type of excellence, and, as it once grew, it has not been equalled by anything that I have yet seen. But even in its palmy days it flourished only in a limited locality on the western bank of the Hudson River. Immediately opposite, on the eastern shore, it could not be grown with profit. Even in its favorite haunts it has, of late years, failed greatly, though by some it is now thought to be recovering something of its old vigor, under high culture and upon new land. As it is such a splendid variety, the fruit always commanding the highest prices, I have set it out quite largely, intending to try wood ashes as a fertilizer.

I have a seedling, which much resembles the H. R. Antwerp in its fruit, from which I am hoping great things. But the plant itself is very different. It originater by chance, in an old garden in the city of Newburgh, N. Y. A fuller description of the locality will be given hereafter. Its roots were intertwined with those of an old grape vine and currant bush, and it has never had half a chance. But it produced such fine fruit as to attract much notice, and my cousin, Mr. T. Hazard Roe, was induced to mark and leave it for future observation. During the summer of 1874 it made a vigorous growth without any extra stimulus whatever, one of the canes attaining the length of fourteen feet. It received no protection at all throughout the very severe winter' of ' $74-5$, the canes merely being left upon the grape arbor. Its appearance during the fruiting season of 1875 is thus described by Mr. Bensel, editor of the "IInme, Furm and Orchurd," who carefully examined into the merits of this new candidate, and says: "Two or three year's ago a raspberry plant sprang up in the garden of Mr. T. Hazard Roe, in this city, which was permitter to grow as a matter of curiosity and because it insisted upon growing. The seedling was not laid down nor otherwise protected during the winter, but each year increaser the number of shoots, which bore fruit to the tips. The present season it is a most rigorous 
plant, or hill of plants, one of the canes measuring fourteen feet and bearing large raspherries in their different stages of growth, in great profusion, along its whole length. This cane was unprotected throughout the list severe winter, and this is sufficient attestation of its hardiness. The wood bears all the appearance of the true raspberry, but is lighter in color than the IIudson River Antwerp. The berry has the beatiful color, and is the equal in size, of the Tudson River Antwerp); slightly conical; not quite so rich, to our taste, as the Antwerp; and hard enough when fully ripe, to bear carrage well. Mr. F. P. Roe, of Cornwall, we understand, will propagate and have sharge of the plant which gives promise of such great usefulness."

I picked a basket of the fruit on a Friklay afternoon, when it was somewhat damp from a shower in the morning, and not in the best condition to be testerl, but after a ride of three miles the berries were in a fair state of preservation on Tuestay of the week following. I thimls it will be firm enough eren for long carriage to market, and yet this question must be deciderl by further experience on a larger scale. It is much firmer than the Herstine and a larger berry. Chas. Downing has seen the plants in bearing, and considers the seedling one of fine promise, but with his proverbial caution and wide experience which make his opinions so valuable, says that it needs more testing under valried circumstances.

I am well aware myself that, like scores of others, it may disappoint all hopes. It takes kindly to its new home upon my Cornwall place. In the fill of ' 74 I removed some plants, and upon one left a cane several feet in length. It stood all through that bitter winter without protection, and the summer following, was loarled with the largest raspherries mon my place. I shall report upon it from time to time, stating its fiults as well as gooul qualities. It is a week later than the Intson River Antwerp, which, I think, is a good feature, as it thus follows carly rarieties and prolongs the season.

Two or three rears ago it was thought that we had fouml in the Ilerstine, the coming raspluerry, but while it is large, luscions, 
and exenllent for home use, I think it will be found much too soft for market. And this is the objection against many kinds otherwise good.

'There are three varieties of rel raspberries, however, that are widely coming into favor for market purposes.

I will mame first the Brandywine or Susqueco, which is a very firm, bright scarlet berry, medium in size, or quite large with grool culture. It is a rampant grower and suckers rapidly, though I have never seen it attaining much height. It is said to be perfectly hardy even in the latitude of Canadis; and at the same time to endure the heat and drouth of the south better than even the blackeap varieties. Indeed it is a native of the south, having been found growing wild on the banks of the Brandywine, and the Indian name of this stream, Susqueco, was first given to it. It should be known by this appellation only, as "brandy-wine," in our day is too suggestive of chemicals and drugs. I find that in New York city both commission men and dealers on Broadway are very decided in its praise as a market berry, saying that it is the only one firm enough to be shipped to a distance.

The next berry in value is the Highland Hardy, or Native. As the Antwerp declined in productiveness and vigor, this variety took its place, and is now grown very largely along the Hudson River. It is indeed very hardy and vigorous. I have never known it to be injured by the winters that were severe upon what were considered hardy kinds. It is also the earliest red raspberry with which I am acquainted, and a most abundant bearer. The berries are small to medium, and carry well to market. Some of its growers in Ulster Co., N. Y., are making large profits per acre. While it is much inferior to the foreign varieties, it is infinitely better than no raspberries at all, and from the way it behaves with me, I should judge that it could be raised where anything will grow.

The most vigorous and productive foreign rariety that I have seen, is the Franconia, a large, roundish-conical, firm, delicious berry that remains long in bearing. I have continued picking 
from my canes fire succescive weoks. It requires winter protection and well pays for the trouble. Where this variety succeerls, it maty be planterl larealy with confindence, ats the fruit is first-class for home use or market.

The amateur will scarcely ask for anything better than Brinckle's Orange, where it can be grown.

We all know about the old fashioned blackeaps which we delighterl to gather in chih!homl: and in molist. rich spots I have seen wild bushes chambering over a fener that problucer as lange fruit as any of the rameded kinds sent ont from nureries with great parade. It least they seem so to ne now. seen through quite a long vista of years. I know howerer that this kimb of distance increases rather than diminishes the objects of our early. wonderment.

The learling variety of this class is unfortunately named "Doolittle," which howerer hats dome so much that it ranks first. in vigor and productireness. and is the farorite for market. Next in value comes the consideribly lincer and later berrythe MeCormick or Mammoth Cluster. With these two kinds one might be quite content. But there are others, and also new claimants, that are well worth a trial.

At the close of this chapter will be foumd a fuller list of those that are now somewhat prommently before the public.

\section{Soil and Situation.}

Tue red raspberries, especially the dhoicer kinds, prefer at rich moist loam. and will do well eren upon quite a stift, colel clay, if it is not wet. In erery case there must be thorough drainage. Upon light, dry, sandy soil. the large foredgnt varieties cammot he raised profitably except quite far to the north. and in the south they can scarcely be grown at all, meler any dircmustances. But the vigorous native redi rasploeries, like the Suspuecon and Highland Inardy, or the blackeapl fimily, will flompish almost. anywhere, north or south. Still, if one has a deep. rith. moist field or garden plot, there can be grown premium (rops. Raspl- 
berries are not so impatient of shate as the strawberry, and may be profitably raised in a pear, or young apple orchard, as their cultivation will help the trees.

The season can be greatly prolonger by planting early kinds on the south, and late varieties on the north side of a wall or piece of woods.

\section{Preparation of the Soil, Ferilizers, etc.}

What I have written under this head in the chapter upon strawberries applies, with modifications, to all the small fruits. Thorough preparation is the foundation of all certain success. As the white grub does not injure the raspberry, it is necessary to cultivate other crops before planting only long enough to thoroughly subdue the grass and weeds, and to deeply pulverize and enrich the land. Any good garden soil can be prepared for the plants at once.

For the foreign varieties, as the Franconia, the Antwerps, etc., there is little danger of making the soil too rich. But ground that will produce a heavy crop of corn will also yield large crops of the harly mative and black raspberries. But in every case there must be deep cultivation, thorough cleaning of the land, and draining where there is any inclination to wetness. There is not a garden in the country in which some varieties of raspberries will not thrive.

As a fertilizer, there is scarcely anything better than barnyard manure composted with muck that has been sweetened by a winter's frost. The land should in all cases, if possible, be prepared by deep plowing in the fall, and the manure can be drawn directly from the stables and mixed thoroughly with the soil, as at this cool season its heating qualities are an advantage rather than an injury. If barnyard manure cannot be had, muck, sweetened by the action of frost and mixed with lime, or better still with ashes, is most excellent.

In the treatment of different soils, light and heavy, the same principles apply here as in the case of strawberries. Close up 
and deepen light and porous laurl with muck composts, rotted leaves and sods, and use light and heating minures for cold, heavy ground.

Bone-dust, pourlrette, etc., composted with muck, sods and leaves, make excellent manures in every case. Top dressings of wook ashes are always good, but never fail to give the land deep plowing, or, in the garden, trenching, as this prevents loss from drouth.

\section{Plants and Planting.}

In stocking a new place, or in obtaining new rarieties, plants must be bought, and, as we have said before, it is always best to purchase of trustworthy dealers. Most kinds propagate themselves rapidly, and a little liter we will show how this process can be hastened. In buying, insist upon being furnished with young and well rooted plants.

Raspberries may be set out to advantage both in fall and spring. In our latitude and in most soils, I would prefer fall for the red raspberries which are propagated by suckers, and spring for the blackcap and purple cane varieties that are increased by roots forming at the tips of the canes.

My plan with red raspberries has been to purchase or take up the plants and set them out in October or the first week in November, if mild. Where the valriety is very choice, I have quite large holes dug to the depth of eighteen inches and the bottom filled up with good surface soil. But in gardens and where the ground has been deeply prepared, this is not necessiry. If I intend to cultivate them with horse power both way's, I mark out the ground into squares of four feet and put two or three plants at each corner, setting them in the ground one inch deeper than they were before. At this distance and where two plants are set in a hill, 5,444 are required for an acre. After I hatre finished planting, the ground is perfectly level, and in after culture should be kept so. I then sprinkle orer and around the hill a shovel full or two of old rotted compost, which, leaching down 


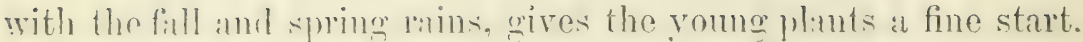
I next cut off the tops or ames a little above the gromul, and mound the enth entirely orer them as winter protection. The first cannot injure them, and the work of planting is done when usually we have the leisure to to it well. Early in spring, as soon as the hard frosts are past, remove the mounds from orer the hills and leave the ground level.

Do not let long tops remain on the plants with the view of getting fruit the first year. Where this is done the usual result is few and poor berries the first year, and scarcely any at all the next. All the plints can do the first season is to establish thenselves and send uj, canes for the next year's fruiting., Even where berries are desired at once, one or two buds left on the shortened canes just above the ground will produce more and better fruit than if the same canes had been left three feet high. I should judge that fill planting would be still more advantageous south of New York, but they will need the same protection, as there is more freezing and thawing where there is but little snow.

But in many localities, and especially to the north, spring planting ansivers equally well, if not better. But let it be done as early as possible, or else the little buds just above the roots, which make the canes for future bearing, will start to grow and thus be broken off in setting. The ground should be thoroughly prepared by deep fill plowing, and again plowed and harrowed in the spring. If all the preparation has been left till spring, let it be very thorough. Nothing is gatined by haste and slighting. Do not plant when the ground is wet ant sticky, unless it be just as a good rain is commencing. Press the soil down quite firmly around the plants, alter filling the holes. Do not at any time, put manure in the hills so that it will come in contact with the roots. Spread it on top of the ground over them, and the rains will take it where it is wanted. Many a tree and plant is injured, if not killed, by placing green, strong manure directly upon the roots. But a top-dressing of manure of any lind is of great value to the young plants, both in fill or spring setting, as it gives them a good strong start at once. Olı rotted compost has the best effect, and 
wood-ashes are also excellent. Plants may also be set out duringe the summer, as will he explained under the heall of proplatiting.

In om latitule, and to the north, the blackeap raspluerries do better when set out in the spring: To the south, and in warm, light land, they thrive equally well after fall planting. These should be put five feet apart each way, as they are rery strong: growers. At this distance 1,742 will be required for an acre. While deep plowing and clean culture are as beneficial to these as to the red rarieties, they do not require as rich a soil. Set them down so that the little hull which makes the new growth is one inch beneath the surfice in heary soil, and two inches in light soil. Cut off all the old cane.

\section{Propagation.}

TuE first effort of the young raspherry plant, after transplanting, is to become established. and next to mopagate itself. About all it can to the first season is to take a goorl root hold mon the soil, and throw up one or two shoots or canes. But the second season the roots of all the red raspljerries (except the purple cune family) which have been sprealing laterally through the soil, show a tendency to throw up new shoots which are termed suckers. With some varieties this disposition is so strong that these suckers will fill up all the spaces between the rows, and choke the bearing hills. For most mactical purposes the red raspberies will propagate themselves fast enough in this way, and unless new plants are needed, the suckers must be treated as weeds and all cut out with the hoe, save four or five in the hills.

But some varieties do not sucker readily, and in introducing new varieties it is often profitable to hasten nature's msual procedure. In doing this there is scarcely a limit to the results of skill and good management. The practised garlener who has glass forcing-houses, can take the smallest roots of at scarce variety and cut them into half-inch pieces, and from carch one make a new plant. Then as they begin to grow he cam talie the new green wood of the little plants. and rut this into small pieces 
which, in sand, and the warm humid air of the proplagating house. speedily set up an independent existence. Thus from one plant thousands can soon be grown.

But eren if we have no glass we can accomplish a good deal with root cuttings. Take up the plants that you wish to increase very carefully in the fall, following each root so as to get it all. Leave enough on the plants to start them well the next season, and then they may be set out again as before directed. Take the roots you have cut off and divide them into pieces three inches in length. Prepare a box by boring holes in the bottom so as to give good drainage. Put a layer of leaves over these to prevent the soil from sifting out, then a thin layer of fine moist earth. Upon this place a layer of the roots, next earth, then roots again till the box is nearly full. There should be two inches or more of earth over the top layer of roots. The box can then be burierl upon a dry knoll beneath the action of frost; or it can be placed in a cool cellar where the roots will not freeze and where they can be kept moist, but not wet. In spring, as soon as the ground is dry and warm enough to work, the roots can be set out in rich, finely prepared soil. Set them slanting a little and in drills, four inches apart in the row and one inch deep. In light, porous land they can be put down two inches. A top-dressing of fine rotted manure will greatly stimulate the little euttings. They should be covered about an inch deep with a mulch of straw or dead grass and, if kept moist by oceasional waterings, nearly all will develop into good strong plants.

There is often advantage in summer planting which may easily be lone at any time from Jume till August, if the plants are upon your own place. Have the ground which you wish for raspberries thoroughly prepared and ready early in June. Take up the young suckers that are from six inches to a foot high with a large ball of earth around the roots and put two in a hill. If this is done unon a rainy or clouty day they go right on growing and make strong canes by fall. Thus a year in time is saved as these may be permitter to bear a partial crop the following season. 
The blackaup rarieties do not throw up - suckers lut are propagated by their tips taking root. This they will do to large extent themselves if not in an exposed position where ther are whipped about by the wind. When new plants are tesired it is best to layer the tips by avering them with two or there inches of earth. This is lone with a carden trowel, and in om latitule, in August and September. The time to do it in crory locality is indicated by the tips of the bushes swelling and tuming purple. They will then readily take root if coveren with a little soil. As new branches grow, bend over and touch the ground. many more tips will be rearly to take root. If a liare number of plants am wanted it will pay to go orer them often in September and () dotober, covering the ends. I have fomm it more satisfictory te leave these young plants in the grouml till spring bat as hat been stated before. they can be taken up and set ont in the fall il desired. But in most localities the frost will tinow them ont if not protected by momnding the earth sliehtly ofer them and then meovering early in sping. The bushes ma be trimmerl in winter if more convenient, as it roes not hurt the romig flants to be separated from the parent at this season.

\section{Culture for Fruit.}

In the garten where the plow will not he used, the plants may be set out three feet apart meh way. If planted in the iall cover with earth as before directer. As early in the spring as the ground is fit to work, montel and fork the gromul decely between the rows. I would rexomment that the spaces betweren the hills be covered at once while the soil is loose and moist. with a heary mulch of latres, rakinger of the law or any coatris? litter that wiil keep the surface damp and the weels from growinge. By fall the plants will have sent ulp new (aness on which

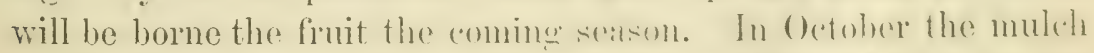
ean be dug under and thens the suil is kept rich. Ahout the lat of Norember shorten in thr romg ames from ons-thirel to onehalf: and you will get more and better linit and the plants will 
hrestremthenol. If a eane is six feet hich I wonld reduce it to fom foret. If a cane is but three foet in height I would not leave more than eighteen inches to bear the next season; small canes show a lack of vigor which must be increased by pruning. If there are side branches, I would cut off two-thirds of their lemeth. This is ono of the aties in which we suffer loss through our avarice, and usually it takes years of experience to teach one to prume his rasplorries and walpevines with sufficient rigor. I was once taught a very useful lesson in this respect. I had some raspberries which were called harly. They were up to the point where the snow covered them-about two feet that winter, but the tops were killed. From those canes, but two

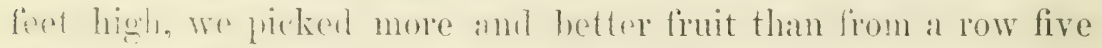
feet in height that lad been covered. Where the ground is nieh and the cames rigorous I think that three and at half to lour lect is a wool height. Early in November or just before freezing weather. hend down and cover with earth all the foreign and half-hardy kinds. The best way to do this is to let a mau throw a spade full of earth up against the hills on one side. Then let $n$ boy bend the canes (all in one direction) gently down over these little mounds, which prevent their breaking by making too shapl an ande. while a man covers them with earth. The work can be done fir more ripidly, by two men-one working on each side of the row, and by this method a great many plants can be covered in a day. It is best to cover them well, so that the rains will noi wash the soil away and uncover the cimes. Harly in spring alter the heavy frosts are past, first

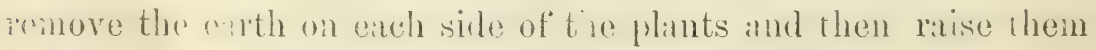
by plicing a fork atrefully under the ends and lifting thein gently.

Early in spring place stakes by the side of the hills with a crow-batr and tie nu the canes at once, using soft but strongtwine. Tie up the ends of the cames sungly as well as lower down, otherwise they break with the wind or their burlen of fruit.

Next lousen the ground thoroughly between the rows with a

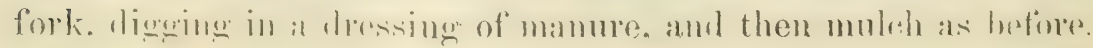


The tops of the raspherries are biennial, the roots pernnial. The anes that wre covered during the winter will bear the fruit and then besin to die. $\Lambda$ s soon as they are thruogh hearing they shomld he ent out close to the ground, and cirriod alway. In the mointime, the roots have sent up new eanes which will hear the following season. In October the mulch can again he dug minler, and the canes buried in earth just before the gromm fieezes. 'This nethod can be kept up a long time. Plantirtions of raspherries have remaned productive for twenty years, but usually they begin to fail after ten or twelve. They should then be dug out and flantings marle upon new grouni, and three or more years elipse before returning them to the same spot.

From three to five canes are enough to leave in a hill. The number depents upon the vigor and branching hab it of the variety.

If one does not like the method of cultivation hy mulching, he can keep the soil clean and mellow by the frequent use of the hoe. I prefer a long blunt-pointed one that goes leeply into the ground without cutting the roots. But I think that in garrlen culture the mulching is of great advantage, not only in keeping the gromel moist, mellow and rich, but in preserving the fruit from being splashed with mud by the heavy showers often prevalent at the time of ripening. I have seen many quarts spoiled from this cause.

Where the harrly varieties are raised, the treatment may be the same, with the exception of winter covering, which is not needed. If the blacksap varieties are cultivated in the garlon, the plants may he set three feet apart in a single row. 'Twenty plants of the Doolittle, and the same number of Mammoth C'luster will abuntantly smply a large family. If the latter can be placed in a cool moist place on the north side of a wall, the season of fruit will be greatly prolonged. 


\section{Field Culture.}

Afren thorous preparation the plants of red rasplopries may be set out in spring or antum fom feet aprat each way, arering them on the anproald of winter as before directed, if not harly, and uncovering arly in spring. We are now getting such good varicties of hardy kinds that it seareoly palys to plint the tender ones on a latere seale, except in localities especially suited to them. As soon as plants are set out throw one or two shovelsful of rich compost orer and arome them. Keep the plow. cultivator and hoe at work, so that the ground is alwatys loose and clean. If tender, cover just hefore freozing weather. This ean be done rapidly by letting a boy bend them orer, while a man fistens them down by a shorelful of earth. Then. with a plow throw a furrow over them upon each side, and go over them again with a shovel, to make sure that all are well covered. The hardy kinds will need no frotection, althomgh a shorelful of fue compust, thrown over the roots in the fall, will give them it strong start in the spring. Cut out the oll canes as som als you are through picking, as these are now' worse than useless, and will absorb much of the root power in their slow decaly, which should go into the new shoots. Put stakes of five feet in the hills the secoml year, and tie up the anes before the buls swell. As som as the (rop) is gathered the stakes cam be taken up and stored umber cover. Chestunt wool makes the best stakes, and if the part that goes into the eround is charred a litte with fire, they will last much longer. Stakes split out of lieavy wood are more durable than round poles.

I do not believe in the method of dispensing with stakes. The bushes are often broken down by the wind or weight of berries, and mully fruit gets into the basket and spoils the sale of the entire crop, giving the grower's brand a bad character in the market.

Unless new plants are wanted for use or sale, treat the suckers as weerls. leaving but from four to six in a hill, accorling to 
the rigor of the variety. Where many statiers are grown, the best results in fruit cannot be obtained.

When a plantation herine to fail. higher manuring will reinvigrate it. IToul-ishes and muck are excellent stimulants. Mulching even on a lirge scale, where leaves or marsh hay is

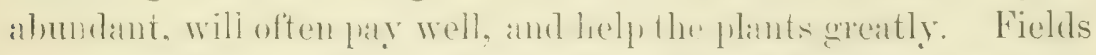
cam also be remewed by letting suckers stand between the rows, and digcring out the old plants. But after a time it will become evident that the land is exhansted of rasplorry food and new plantings should be male elsewhere.

If blakeals are to he plowed both ways the stools should be five feet apart, but if the eultivator is to run only one way, let the row be six foet andit, and the plants thee feet in the row. If black lasploreries are planted six feet hy three. 2,400 will be required for an acre; if six by four feet, 1,742.

\section{Varieties.}

Ir the following partial list I have merely named those that are now more or less in faror.

Hudson Rivor Antwerp - Ineretofore the great market berry mpon the west side of the North river. It is very large, firm. somewhat dry, molky in flitror, early, and continues long in bearing. Where it and he grown it is the best of the foreign rarieties. It has declined in rigur greatly for sereral years, suffering much from millew, and general debility. not ripening its wood. It is therefore being supereeded by other lime in its old hames, especially hy the Ilighland Irarly. But I think it can still be grown probitably on new. rich. moist. but well drained suil. It once yielded enomous arops and bromght its growers at great deal of money. It must be well covered with carth before severe frosts.

Eranconian-Perhaps the hest amb hatrdient of the foreign

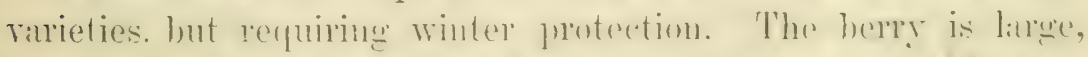
romulish, of geon flitror and firm enumgh for mitret. It con- 


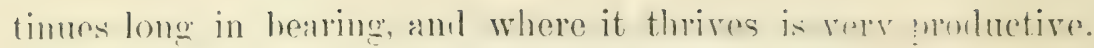
Like all the foreign varieties it requires high culture.

Belle de Fontenay, - Some assert that this villicty and the Amazon are identical. A large berry but not very firm, deep

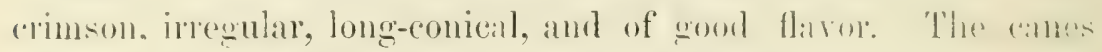

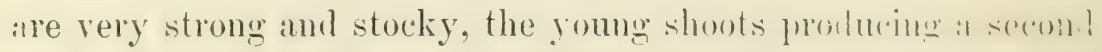
crop in autumn. It is the best of the fall-bending varieties. It throws up an entless number of suckers, which must he "ut off as soon as they appear, if much fruit is desired. By anting off the canes even with the ground in spring, the new shoots will produce quite a large crop in the autumn.

Belle de Palluaus-1 hright crimson, large, ohtuse-conical berry, of yood flaror. firm and productive. I should think it might become one of the hest of the foreign kinds for maket.

Hornet,-Very large and fine, but very uncertain in most. localities.

Brinckle's Orange.-The amateur's variety. ()range in color. large, obtuse-conical, and of delicions flavor. The canes are strong and the plant very vigorous and productive.

All the above virieties need careful winter protection and high culture.

Clark, - This variety is almost hardy, though its tops have been killeri in my garden. If held llown by a shovelful of earth, it will endure almost any winter. 'The fruit is large, especially if the canes are cut back rigorously, and of a sweet, rich flavor. It is too soft for market. but excellent for home use.

Philadelphias - This is another varety that needs but little protection, if any, and where quantity rather than quality is: desired, is one of the best to plant, as it is the greatest bearer I have seen. But the fruit is dark, soft, and of poor flitvor.

Herstine-A large, beantiful, fine-flivored berry. excelient for home use, but too soft for distant mirkets. It is proluctive and a very strong grower, doing well even on poor soil. 
Saunders,-It resembles the Iferstine but is usuilly not so productive.

Turner-A fivorite rariety at the West. IIedium to lintre, quite prolific, moderately firm, and ripens its crop early. It is said to be hardy.

Highland Hardy,-The earliest raspleery aml very valualle on this account as well as for other reasons. It is very prouluctive, perfectly hardy and thrives on almost any soil. The liruit is medium in size but improves greatly unter high culture :mol rigorons pruning. It is fast becoming one of the chief matret berries.

Brandywine or Susqueco,-I'his is mobably the best of the red raspherries for field culture and has already been quite fully described.

\section{Blackcap Varieties.}

Doolittle or American Improved,Lirge, juice if well fruned and grown on good moist land, very vigorous and enonmously productive. It is the best for the general crop.

McCormick or Mammoth Cluster,-Very linge and al werk or ten days later than the above, a very strong grower and exceedingly productive. One of the best.

Miami.-Resembling the Mammoth ('luster but not equit in it in value. It is brighter colored and may therefone fare berter. in market.

Davison's Thornless,-The earliest biackealy that I have seren.

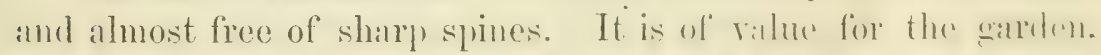
but not sufficiently vigorous and produetive for field enlture.

Fay's Thornless-said to be better than the Darison.

The Ohio Ever-bearing,-Latre and of wood flavor; at stronge

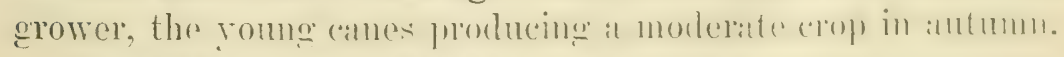

Farly Cluster and Ontarion-New and promisin unedling. 
Ganargua, - I hylmid between the red mopherry and blackeal', and is and to be hatrly, early and proluetive. The berry is laree. firm and fine flavored, but its color will prevent its becoming at farorite in the market, as it is neither red nor black. It is a strong grower, and is propagated from the tips.

Norwood,-A new varicty that is highly spoken of in some quarters, and slightingly in others.

There are new rarieties of oreat promise which must he tested still further before any correct opinion can be formed concerning their merits. First among these I place my seedling,

\section{The Pride of the Hudson.}

But pride often has a fall. and my promising berry may soon pass out of notice. It certainly shall if it does not prove rorthy of its name, for never shall I consciously commend a poor fruit; and if it be my own, I shall be still more critieal. The Cuthbert and Delatware rasplerries have been spoken of very highly, and I hope to be able to report upon them and others from time to time.

If one wishes to raise new varieties, let him select the finest berries when fully ripe and mash them in dry sand till all moisture is absorbed. Sow the seed in the fall about one-fourth of an inch deep, and sift over them some finely pulverized muck, the greater part of which should be raked off a awin early in spring. What the seenls require is slight covering of very fine, light soil which must be kept moist and at the same time have no tendency to bake or become hard. They will then germinate early in spring. Protect the young plants the following winter and set each one out singly the following spring; number them, and in albut three years from the time of sowing you can learn the value of the new varieties. The subject of picking, marketing, ete. will be treated hereafter. 


\section{CURRA NTS.}

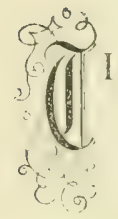

IIE culture of the currant is beeming increasingly pofitahlo every year. The briefness of this chipter does not indicate my estimate of the value of this fruit, but its cultivation is so simple that but few words of direction are necessary. A deep rich soil, clean (ulture, mulch, and the pruning linife are the secrets of sucess. Strageling currant hushes along old fonces and hall-smothered by grass and weels are not the models to be recommented. It is pretty ham to kill a currant bush, but only by the following methods ran prying erops be raised in the garden or field.

A moist, heary soil is the hest, but hiph manumand mulching will make any answer. It is liflicult to enrich the soil ton highly as the comrant is a gross feerler and not particular as to quality. Wool-ishes howerer are specially excellent. I)ep plowing in preparation, clean culture and mulching, will go al great way toward making up for lack of fertilizers.

Set the plants of the white and red kinds four feet apart each way and lieep them in shape and homols by fruming. At

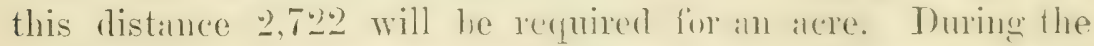
first two years let the spares hetween them he kept dean and mellow by the frequent use of the plow and cultivator, kecping the ground level. The third year a paying crop may be ex-

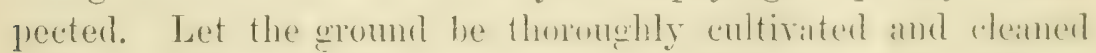
as early as possible in springe working in a heary tophlyessing of compost or any manure that can be had. If a mulch of leares or any lind af litter an br put on at once while the 
gromml is fresh and moist all the better. But if such material is not at hand. wive the eround in the grarten a thorough hoeing or light forling rarly in Jume, and then scatter over it, between the bushes a mowing of coarse weofy grats that is not fit for hay. Where currants are grown liarely I believe it would pay to ricise ordhat grass for the purpose of mulching. This stats early and a heary burten cam be mowed eren in Maly. Mulch, by lieeping the gromel moist, langely increases the worght of the (rop. In the sonth and upon light soils it is indispensible to any profitable sucerss. Ioreover, where it is not used the fruit is crenerally barlly splashed with mud, and only clean handsome fruit brings paying prices.

L.s any part of the vood becomes old and munoductive cut it out. Keep the bushes thimed, strong and rigorous. Six or eicht stucky shoots will produce more and better fruit than a much lareer bus: full of thick tingled branches and oll wood thromeh which air and light camot circulate. Cut out in spring all the young suckers except what are neerled for the remewal of the plants. Bushes usually become unproductive through over-crowding of young and old wook, till at last there is little else save wool and leares. Strong and long shonts of new wood should be shortened in the fall or early spring, and this young growth employed in producing new plants.

\section{Propagation.}

The currant can easily be increased by cuttings. The best time to make these is the last of September, or as soon as the

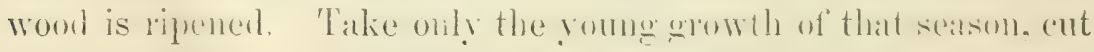
the shoots into lengths of six inches, strip off the leaves at once, if they have not alrealy fallen, set the slips out in rich, moist. but well-riatined land. Sink them down so that only three buts are left above the surfice. Jet them be in rows two feet apart and six inches in the row. 'Top-dress with fine old manure, if possible. By winter they will be quite well rooted, and in the following seisun will make ai rery strong growth. When two 
years olil they will he fit for sillo ol home plantin!... While many one year plants are sold, and if vigorous are just as grool, if not

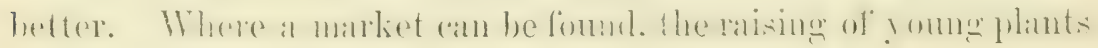
is a profitable business.

While the best results are secured from early fill cuttings,

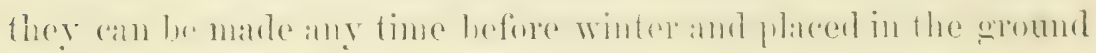
as directed above. I have found it advantageous to mound the carth orer them, arering them completely, and then meorering early in the spring. This prevents the frost from throwing them out. If it is not convenient to set out the cuttings in the fall, they ean be tient in bundes and huried in the open gromul just beneath the action of frost. Put them out in rows as early as possible in the spring. Cuttings can be made any time during the winter and hures in a cool cellar, keeping them barely

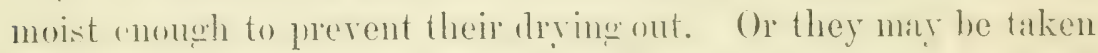
from the bushes early in spring. and if sct ont in moist land, will gemerally live, hut do not make as goor a growth as those plinted early in the fall.

The old firlioned way of layering or bending down branches ju spring, and throwing eath upon them here and there never fails, but the plants are not as nice as those producerl by cutting's.

\section{Enemies.}

THe currant has two enemies which in some seasons and localities, if not interfered with, are very destructive. 'The more formirlable one is known as the currant worm. It is about an inch long, hright yellow, and dotted with small blate spots. These worns are very romatous and will strip the bushes ol foliage before one is atrare of their presence, if not on the watch for them. The remedy is a therough dusting of white hellohere mpon the leatres when they are wet with dew; or hetter still. put

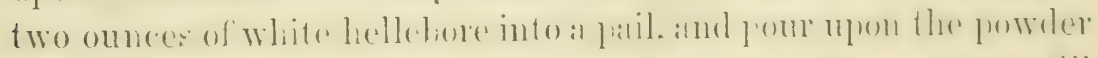

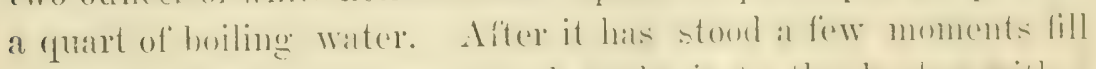
up the pail with cold water, and aplyly it to the bushes with at 
symere. The liquid kills erery worm it touches. Applications should be continued while any of the pests remain, and if attacked in time they can soon be destroyed.

The other enemy is a worm called the currant borer, and its presence is known by the wool shriveling, or the foliage turning yellow. Cut oft the infested branches close to the gromul, and burn them. If eurrants are grown in bush form, which is the better way, they can sellom restroy a plant, but when the plants are promerl into miniature trees with in single stem, the borer is often fatal to them.

'The same general principles apply to the culture of black currants, only bearing in mind that being langer and comser in their growth, they require more room, and need less pruning.

\section{Varieties.}

Thene are but comparatively few kinds of cmrants worth cultivating, except as the amatem ammses himself with variety. I shall merely name those which are best, and which furnish all the qualities desirable for home use and market.

Old Red Dutch,-.'Ton well known to neel description. But if those perple who leave their bushes to fight with grass and burlorks, and to finit upon the same wool for generations, should happen to see this ohl friend enjoying good cultivation amel rigoroun frming, they would leclare that it was a new and (hoice variety. I have been toll al instances where this common Reel Duteh was sold in market for Cherry currants. There is scarcely a fruit which high altivation improres more. and it is an ofen question whetier it is not the most profitable kimb to mise, since, from its enomoms hearing qualities, what is lost in size and showiness is male up in weight. I find that many are inclined to think that if it received as good treatment as Cherry and Versilles, it would be equally profitable. It is also one of the sweetest and best flavored when fully ripe.

Cherry - The largest and most showy of the red currants, 
and the great market rariety. It is acid and not first quality in flaror, but its heauty and size make it the farorite for market. The bunches are rory variable, some being small, and consisting of only two or thee herries. others quite long and larese. hui not tapering like other kinds. It is a conve grower and pross finder, repuiring rich soil and high cultivation. The yomes shots are very strome and stocky. The hushes need a great deal of judi-

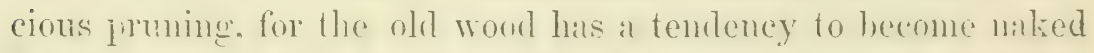
and barren. Sut in most localities it is one of the most profitable crops that can be raised.

Versailles, - If this is a ristinct variety. it resembles the Cherry so closely that it is difficult to tell them apart. It is claimed that it is not so acid, and that the bunches are longer and more tapering. Eren so high an authority as $\Lambda$. S. Fuller writes:

"Although I am not reary to say positively that there is no distinct variety to which the mame Tresilles helonges still I have not yet heen able to obtain one in which really distinct and permanent variations can be discorered. I shall he most hapy to receive any information from other growers which shall enahle me to decide this rery perplexing question." Mr. Downing says that the nifference consists in some of the hunches of the Tersailles-not all of them-being longer and more tapering than those of the Cherry.

I have made two large plantings from stock that amo origimally from Charles Downing's plike. and which I hand to lw sume. and shall carefully observe all differences. But those purrelasing the Versailles with the expectation of getting somethine rery different and much better than the ('herry should be mulecerved.

Victoria,_This is a valuable liste variety large and of hright

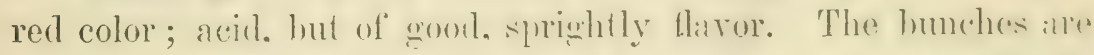
very long, and the plant morleritely rigorous and exerenlingly productive.

White Crape--The hest ol the white curants. latere, trans- 
larent, rery beantiful. It is sweet and juicy, amel of exoellent flavor. The plant is quite vigorous and very productive.

White Dutch, - It resembles the Red Dutch, with the excrip-

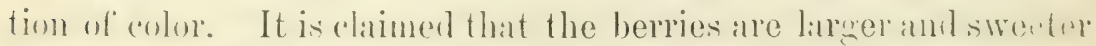
and the bunches a little shorter. The plant is rery rigorons.

Black Naples,-Very litrge, biack and of a sweet musky flaror; a strong grower ani productive after the bushes hare attained some size and age.

There seems to be an increasing demand for blark currants. but white rarieties find but a limiterl sale, thom the best. For home use the latter should always be cultivated.

Buist's Long-Bunched Rorl, and Fertile de Palluan might be adter to the list, hut for all practical purposes the above described varieties are sufficient. 


\section{TOOSEBERRTES.}

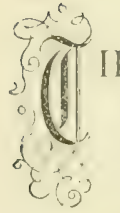

IIE treatment and propiagation of the gonseberry is almost the same as that of the emrant. Suecess depents mon drep am thorough prepration of the soil, abundince of fertilizers, and rigorons pruming. Unless the plints are liept growing vigorously the fruit som lloteriorates and mildew is more likely to ensue. Cool northern exposures and leep, moist soils should be selected when possible.

Cuttings can be made in the fill. hut sucesed equally well, if not hetter, when mate early in suring. as the wood of the gooseberry is slower in ripening than the "urrant. When the plants are large enough to set out, jut them fom foet apart each way. They can be prumed to a single stem if desired, as the borer does not often disturh them. But I prefer the bush form, as it gives more opjortunity for renewal wilh yome woot. As the bushes grow in size keep them thin and opens so as to admit an abundance of air and light. As the wom hecomes old and mproductive, cut it out.

The gooseberry, even more than the currant, is impratient of weeds and slovenly culture. Ilarilness and dryness of soil is especially injurious, and therefore mulehing is of rery great advantage.

If the currant worm aljours on the foliage it should be destroyed with hellebore as I have alrearly directed.

Mildew is the great foe of the gonseherry in this antry. and often attacks not only the finit hut the plint. There is no certain remedy, and it is best to plimt only those valdedies which are seldom or never affected by this scomge, if there are any 
such farored kinds. I have been told that even the Houghton mililuws in soms locilities in some seatons. Still in most instances our hardy, native varieties are free from rust, if grown on moist, rich. well allivated lam! aml well prumed. Sometimes a ereat many yome suckers will start in spring which shonld be cut out. The regular pruning can be done any time after the leares fall and before the buds start in spring. Except for an amateur's experiments, the large foreign varieties are too uncertain for our climate.

\section{Varieties.}

Houghton's Seedling-Ilas been the principal variety grown of lite year: both for winten and field culture. and many barrels are sent ammally to New York market. The fruit is small, almost romed, pale red when ripe, sweet, tender and of good flavor. It is readily propagated by cuttings, like the currant. The plants are very harily and rigorous, and as they grow large, have a spreading, drooping tendency. It is exceedingly productive, and rarely mildews.

This variety is rapidly being superceded by the-

Downing $-\mathrm{A}$ larger and better berry, oval, greenish-white and of excellent flavor. The plant is a strong upright grower, and very productive. It is no doubt the best gooseberry thus far introduced. This variety is sail not to grow as reanlily from cuttings as is the case with most kinds. For home planting it can be increased by layering, or benting branches down in spring and covering part of them with earth. By fill these branches will be well-rooted and can be set out elsewhere.

Mountain Seedling --Larger than either of the two first named but not equal in quality.

Smith's Improved - A strong grower. Berry large, light. green, oval, but not equal to the Downing. 


\section{Roe's Seedling.}

(Namerl for T. Irazard lioe, upon whose platere it miginuterl.)

This is by far the largest and finest gooseberry that I have ever seen, and if it continues free from millew and flomishes alsewhere as in its original home. it camnot fail to sunerereste all others.

Last year, on account of the severe and early drouth, they were not up to their usual size, but during their fruting season I cut a number of branches laden with berries and took then io New York. Prominent commission men to whom I showerl them said that they would bring almost double the price of any in market. I next took them to Prof. Thurber, editur of the Americin Agriculturist.

I saw at once that he was impresserl. Alter exmmining them he remarked with some emphasis:

"That's considerable of a gooseberry, young mar."

Ile at once sent for his engraver and directed that the drawing should be mate which appented in Norember number of the Americun Afyriculturist and is reproduced on the corer of this manual. He also requested me to furnish a histury of the viriety as far as I could learn it. As a result the followinge statement, prepared by Dr. 'Thurber, accomprumich the moraring in the Agriculturist:

"Sometime last summer the Rev. E. P'. Roe, of Cormwall-onthe-Hudson, brought us a specimen of at wouselerry, in which bush and fruit appealred to be perfectly healthy, and the find was much lareer thatr any of our matives solts, abmulant, and of a fine green color. Upon learning it was a new seedling, we had an

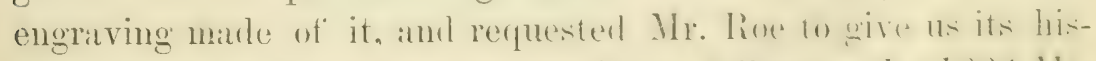
tory, which he has done substantially als follows: - In lseli Mr.

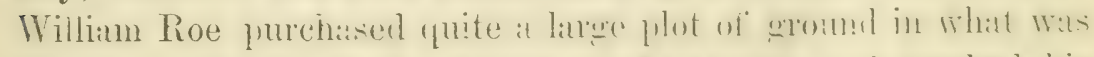

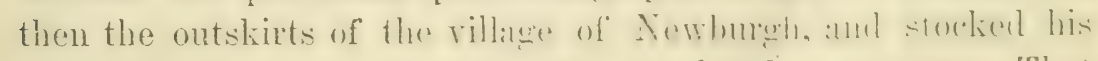
place with the best fruits that he could then procure. That which was then a home in the country, is now a country-like home in the centre of a laren city. Mr. T. Hazand line is lim 
present proprietor, and inheriting the taste of his father, has given his place a local reputation for its fue fruit for many years. Among the known varieties many seedlings were permitted to grow, and there are now natural pears, peaches, and apples on the place, that are very valuable, as well as a seerlling rasplberry that promises better than anything I have yet seen.

"But the seedling gooseberry which I brought to your office is perhaps the fruit of the greatest promise. For many years I had been struck by the remarkable size and firimess of these gooseberries, and supposed that they were some very fine English variety that by some good fortune had not mildewed. Sometime ago I expressed my surprise to Mr. Roe that his gooseberries were so free from rust and then learned for the first time that they were a seedling variety, which originaterl on his place more than fifteen years ago, and that they never had mildewed. I at once concluded that if it could be mide to do as well elsewhere, it would be a great advance upon any variety of this berry I had yet seen. The bush is a very strong grower, and perfectly hardy. The variety will be thoroughly tested in various soils and localities, and the best judges satisfied as to its character, before it is sent out. Thus far I have never seen a more abundant bearer, the fruit being large, green, and fine flavored when ripe."

It is a chance seedling, and nothing is known concerning its parentage.

I have found by experience that the plant is readily propagated by cuttings, and I have now quite a large number of young bushes raised in this way without extra care-no more than I have given to currant slips. Some young bushes have borne fruit on my Cornwall place, with no trace of mildew. I shall be able to test the variety very fully the coming season, and will accurately report the results whether favorable or the reverse. The plants will not be for sale before next fall, and perhaps not until the following year. 


\section{I'H B BLCK BERRY.}

HERE is scarcely a more wholesome fruit than this, and yet the majority are depending upon a precarious supply from the woods, extemporized into a jam by the grimy hands of muknown pickers, when for six weeks together

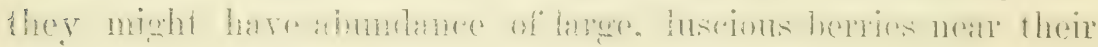
own doors. There is no inuit more easily raised. A Kitta-

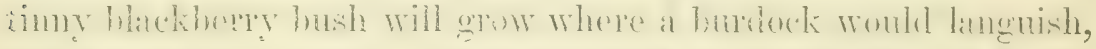
and yet there are thomsands of burkocks to one batcherry bush.

Its enture is rery simple. Select land that is bot very motst

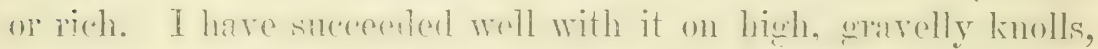
but unless well mulched it is ant to sufter from drouth. Jight, warm lamel, howerere, is preferahle to that which is heary and

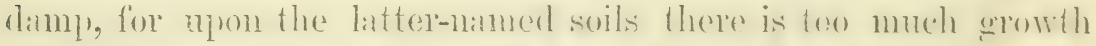
of wool which does not ripen linlly and therefore is killed by the winter's cold. But deep plowing in premaration is always of

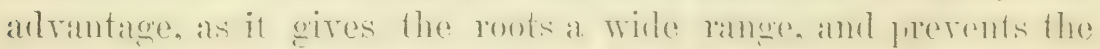
plants from suffering from drouth.

Fall is the best time for planting, lut it does very well when

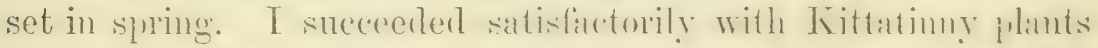
put out late last suring, in spite of the serere drouth that fol-

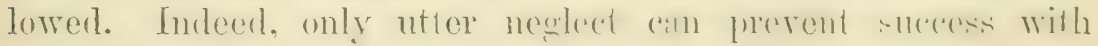
blackberries where they are not winter-killed.

For field culture let the rows be eight feet apart and the plants three feet distant in the rows. If the soil is poor and

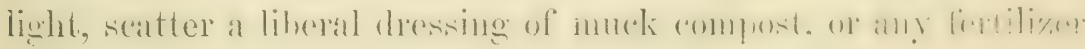
that is not heating, down the furrow in which they are to be 
plinter, and the roots will follow this and throw up suckers along the rows where they ane wanterl, instant of in the mitdle spaces.

In garden culture six feet hy four is a goonl distance at which to set the plimts. There the soil is sufficiently rich, and only' clean cultivation and rigorous pruning will be necessary.

The only difficulties in the way of blackberry culture, are the savage thoms, mampant growth. amb liability to be killed by severe winters. 'The first two obstacles an be orercome by the frequent use of pruming-knife and hook. A little work at the right time saves at great deal of trouble. When a blackberry sucker first appears it is a very imnocent and little affair, and a child can pull it up, but, like a barl habit, if left till fully developed, is most fomidable, and its removal recpuires heroic effort. One might almost as well attark a will-cat as to cople with it bare-handed. When the shoots are yomm and tender, the hoe, knife, or sickle can easily keep then within bounds. Keep the rows down as far as possible to a single line of plants standing one foot or eighteen inches from each other. As fast as the suckers, which are to be left for fruiting in the rows, attain the height of four feet, clip off their tops. This causes them to throw out side shoots, and upon these the hest fruit is borne. They also intertwine tocether, forming a sort of hedge, and thus are able to siand withont stakes. If well-pruned and headed back, all the varioties, except the Early Wilson, cam stand without support. This variety has much of the slender trailing labit of the rmung blitcherry, and needs staking. But cutting it back will greatly increase its stockiness. It may be well perhaps to stake all varietics the second year, for until the plants becone extablisherl, the young canes are weak and slender. The regular pruning and cutting out of the old wood can be left till after the huls swell in spring, making one labor of it. At this time it can be seen which prirts alle alive, and which have been killed by the frost; shorten in the site shoots one-half or two-thirds, and nore and better fruit will be obtained. When the bushes are left to grow very large and bear all the fruit that 
forms mon them. the berrins to not mature. especially if it is dry, hut wow ham and seedr. The pruming in spring can best be performed hy a strong pair of shears upon two long rods which enables one to work at a respectful distance.

The liability to be winter killed is more diffirult to contend with, and in our latitule the Farly Wilson is almost always destroyed, if not protected. It can generally be preserver by pinning it close to the gromul hy a shorel or two of earth, or by keeping it down by laying bean poles upon them, and rovering with tomato vines or any coarse litter. I find that protecting with earth is the simplest and smest way, and at the north I should think it would pay well, for if this variety survires, it yields an early and enormous crop.

The other kinds are such stiff stocky growers that they cannot be bent over and corered, and some winter's seriously injure those that are called hardy. Moreover varieties that are hardy mon New Jersey suml will not endure winters finther north. If we ean get a hacklerry that is as good as the Farly Wilson or Kittatimy and perfectly harly in the high latitules, it will be a great acpuisition. There are sereral new varieties which are claimed to cmelure all temperatmes, hut the same was asserted once of the linds which we sometimes fiml shriveled and dear in suring. No legree of first erer aflects the roots, but only the henring auses. The best preanution in the wise of the stocky growing kimb is to head hack the bushes in summer to the height of three or four feet, thus (ansing them to throw ont sideshoots low down near the groment so that the suow protects them. When we are bitored with mill winters there is seldom any loss. (Only rarely do my vines sufter serere injury. Even to the far moth a for Kittatimy hushes can he protected hy leaning evergreen branches mom then or covering with leaves or any coarse material. They are so nearly hardy that rery little protection answers. But the anes of erery variety that I hate secen, if allowed 10 grow thick and high mon ramk moist soil will almost invarially sufler so muth with the frost as to he muprofitable. 


\section{Varieties.}

For home use I would recommend as first in value the

Kittatinny- A rery laree and delicious kimt that continus: long in bearing. It is a trementomsly strongerporer, and shomld be kept well in dheck by destroying the suckers and hearlin: back in summer. It is also first class for market where late blukberries bring good prices. Its flator when fully ripe is nost excellent.

Wilson's Early,-Quite distinet in its growth and character from the abore, for it has, especially when yomng, something of the railing habit of the ruming hlackberry. For this reason we think it can be grown quite far to the north, lor althongh it is rery temler, and generally liblen by frost in this latitule, it can, from its stemter and willowy nature, be benc down in fall and covered with eartl. In any region where very large and eariy blakberres bring gool prices it will pay to do this. I corer mine conspletely in Norember either with earth or any thing that will kere the canes down close to the gromul. It is the best makthet hery, lnt mess one is willing to give it winter protection it will mot pay to raise it in this latitule. The fruit is rery iarge, black, oblong, quite firm but not of so rich and good a flavor as the Kittatinny.

Dorohester. - I very good variety, int not quite sa prouluetive as either of the above. The canes are vigorous and quite hardy. The fout ripens early and is large, swoet and very goorl. It is regarded as an excellent market variety.

Bnyder - Sanil to be perfectly hardy am rery productive. Fruit medium in size and of good flavor.

Lawton, or New Rochelle._This ohl and well-known raulety is now quite supereerlen by hetter kinds. The calles are very 
tender and are so strong and stocky that they cannot be laid down and covered. The fiuit is not ripe when it is black, and when fully ripe is very soft. But it is large and of very good flavor, and the bushes continue long in bearing.

There are other new varieties concerning which great things are asserted. I hope fuller experience will enable me to report favorably upon them. 


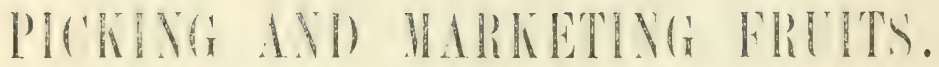

\section{Packing Plants, Profits of Small Fruit Culture.}

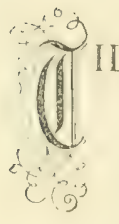

IIE question often arises, after all, do small fruits pay" They pay some people well, and unless location, soil, or climate are hopelessly against you, the degree of profit will depend upon your skill, judgment and industry. The raising of small fruits is like other callings in which some are getting rich, more earning a fair livelihoor, and not a few failing. I to not seek to mislead any one by rose-colored pictures. It is a business in which there is an abundance of sharp, keen competition, and ignorance, poor judgment, and shiftless, idle ways will be as fittal as in the work-shop, store, or office.

Innumerable failures result from inexperience. I will gire me extreme example which may serve to illustrate the sanguine menial condition of many who read of large returns in fruit culture. A young man, who had inherited a few hundred dollars, wrote me that he could hire a piece of land for a certain amount, and wished to invest the balance-every cent--with me, for flants, thus leaving himself no capital to continue operations, but expecting that a speedy crop would lift him at once into a prosperous career. I wrote that under the circumstances I could not supply him-that it would be about the sime as robbery to do so, and advised him to spend several year's with a practical and successful fruit-grower and learn the business.

Must penple enter upon this calling in the form of a wedge. but only too many commence at the blunt end, investing largely at once in everything, and therefore soon taper down to nothing. 


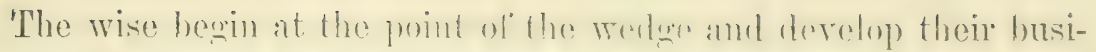

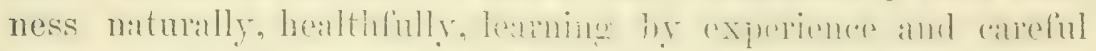

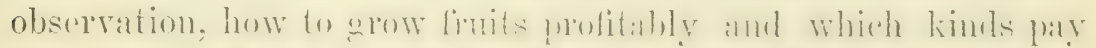

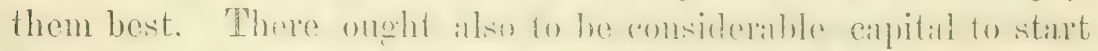

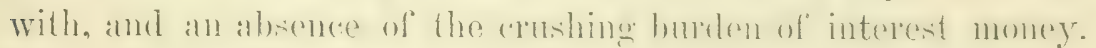
No fruits yield any returms before the second or third years;

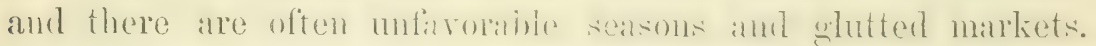
Nature's prizes ane won by lationt porsictent imblustry and not by Wall street sleight of hind.

Location is very important. A fancy store, however wellfurnished, would be a rumous investment at a comutry cosos-load. 'The fruit firm must he situited where there is quick and cheap' access to good markets.

And such matkets may he nealr, and good cultivation produre an abundance of finit, aml still much loss arise form not ponperly

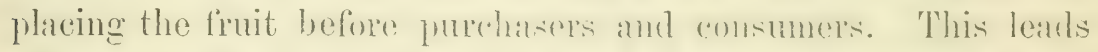

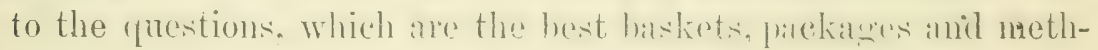
ods of shipping. TVe will commence first with:

Strawberpies - Ifter spouling considerable time in the New York markets. I found fir more diflerence of opinion concerning packages than I expectod. The verdict of the Broadway fancy trade is in firvol of the Beecher biskets, qualts and pints, and for choice raspberries, half jints. IV. and C. Smith, the well-

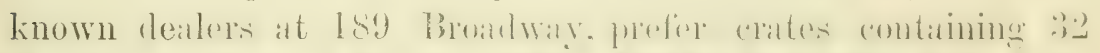

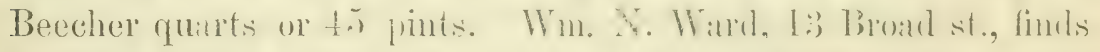

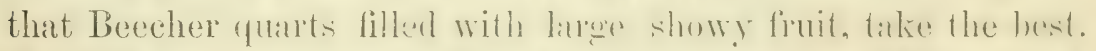

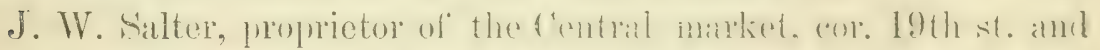

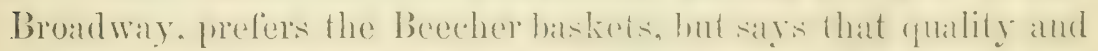

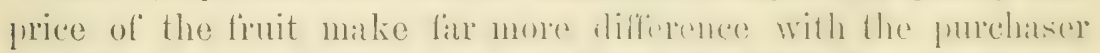

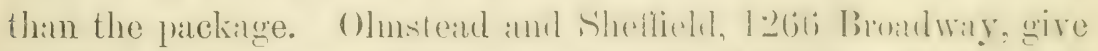

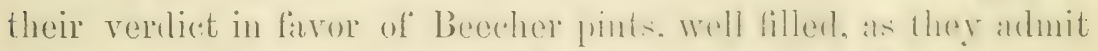

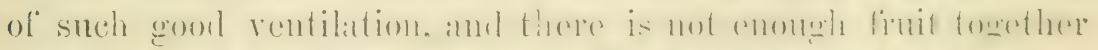

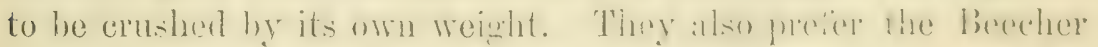

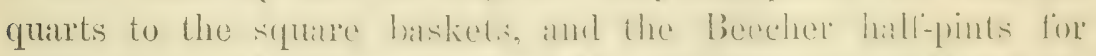
rasploervies. it the same time they would much rather hatre 
hambsome fruit in the sfuntre, than ordinary berries in the round batsets. An fancy kinds, the Juemela, Triomplue, Pres't. Wilder and Momareh are most in firvor with the above named farties.

The following cuts represent them to the eye:

VENEEIR BASIETS

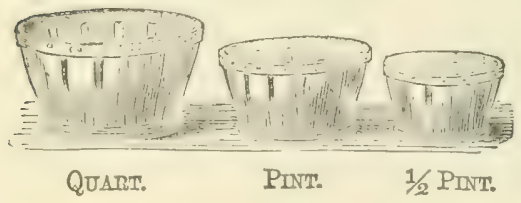

STAR IBASKLTS

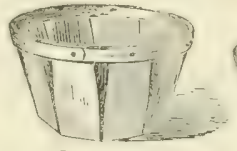

QUART.

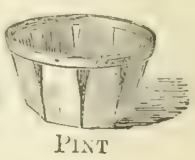

The puints in favor of the Beerher basket, are that they hold a full quart, that their construction gives the fruit plenty of ventilation, and that large, handisome fruit shows better in a round basket. The antrerse points are that their shape caluses them to take up more room in the crate than square baskets, and therefore to require larger packages for the same quantity, and that they do not fit in the crates tightly, the rough handling they often receive jarring the firut out of the baskets and causing them to appear partially filled and unattractive.

The veneer quarts of the above style are quoted at \$3.5; pints at 530 ; and half-pints at $\$ 26$ per 1000 . Star quarts at \$2) cach kind at $\$ 1.5$; f forty-five pint crates at $\$ 1 .+0$. The above gives an irlea of the prices, and for further information the reader can address the Beecher Basket Co., Westrille, Conn.

But when we come to the large, open market and among the - commission houses where after all our fruit must be sold, we find opinion almost equally dividerl between the romd, or Becher baskets, and the square American, or Delaware quarts. It is said in behalf of the square quarts that they can be bought at about half the price of the Beecher baskets, that they fit so suugly and tichlly in the crates that it is almost impossible for rough handling to spill the berries, and spoil the looks of the baskets when the crates are opened, and that packages containing the same amount are smaller and more easily hambled. For shipping long distances, the square, closely-fitting batslicts seemed quite 


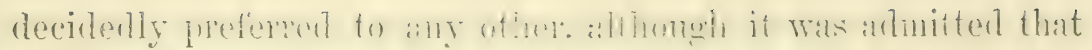

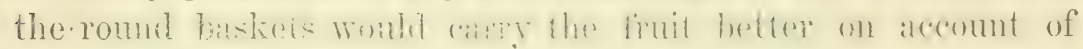

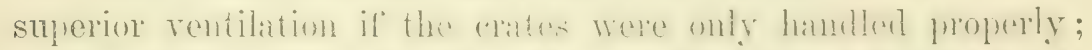

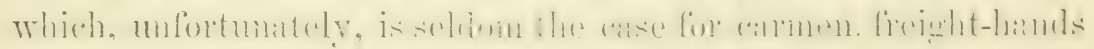

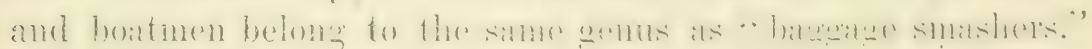
Moreover it is said that the square or American baskets are

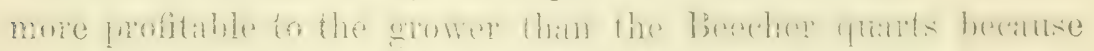

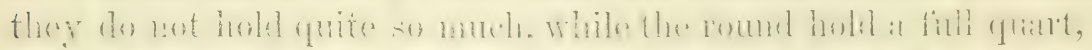

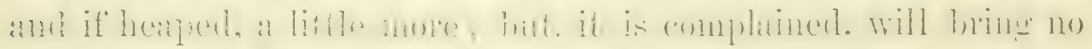
better prices than the square quarts. It is said that, in many in-

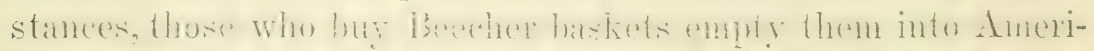

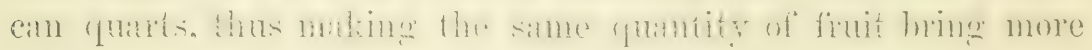
money. This feature should be changer, and a quart basket

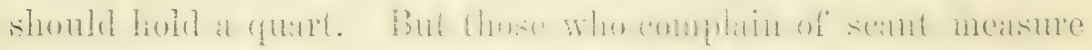
should be willing to pay more for the Beecher baskets. 'The

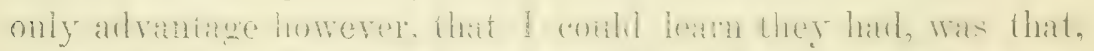

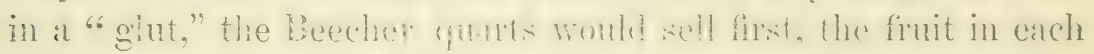

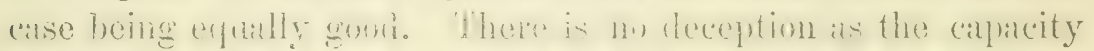

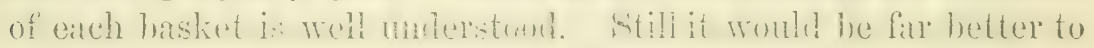

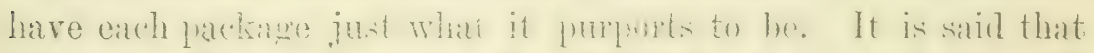

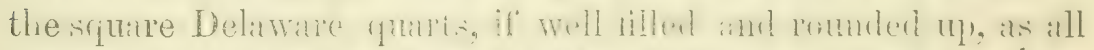

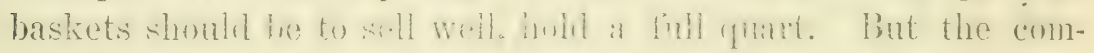

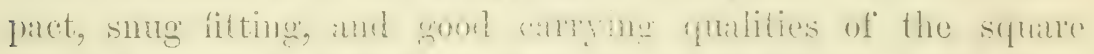

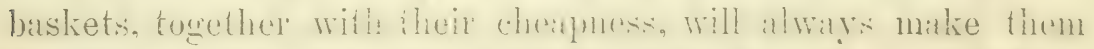

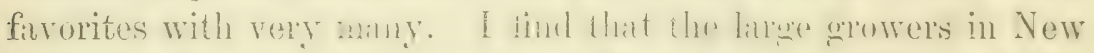

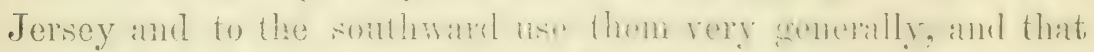

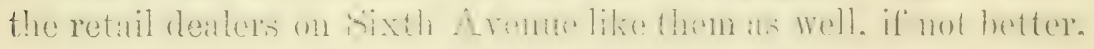

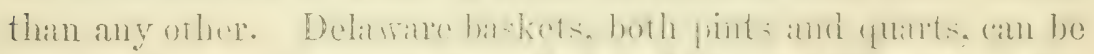

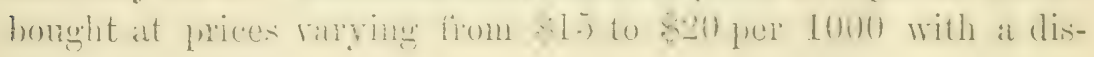
count upon large orders.

It should be said, however, that squar' points and thireds are

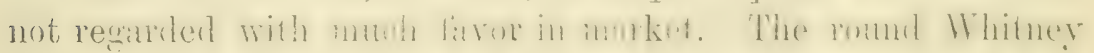

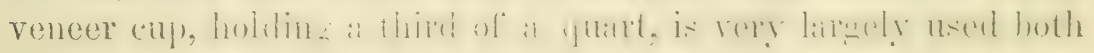
for strawberries and rasplories. The packige has the advan-

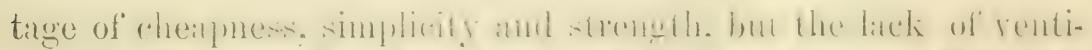

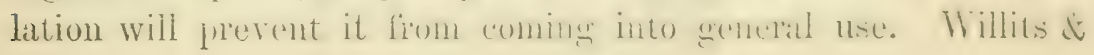


Co, 10:3 Muray st. New Lork, who have hat much experience, recommend Delaware fuarts an! Boceher pints for strawberries and Beecher half pints for raspherries. I am so well satisfied that their views are correct that I shall in the main follow their adrice. The adrertisements of many trustworthy manufucturers of baskets and crates can be found in the agricultural prepers. I have tried to give the realer the pros and cons concerning the two styles most in faror, leaving to him the choice. In view of my nearness to market, and the fact that I shall chiefly grow the fancy rarieties, I shall invest lingely in Beecher pints. For Wilson strawberries I would recommend as a good packige, the Delaware :2 quart crate, and for large berries, the 24 quart crate.

Picking - Haring procured the baskets which suit us best, the next thing is to fill them lroperly, and get them into market looking fresin and attractive. It is just at this point that very many wrong themselves or permit themselres to be wrongerl. The time is past when all strawberries will sell as such at so much per quart. Appearance often doubles the price, or makes it dificult to sell the fruit at all. Soiled, muldy berries, even thongh large, will bring but wretched prices, therefore the importance of mulching. The firut may be in beautiful condition upon the vines and yet carreless picking spoil it. The work is often performed by children, or by those who have hat no experience, or from inherent shiftlessness, do everything in the worst possible way. I have seen beautiful berries that in their brief transit through grimy hands into the baskets, lost half their value. Many pickers will lay hold of the soft berry itself and pinch it an they pull it off. Then instead of dropping it into the basket, will hold it in their hand as they pick others, and as their hamd grows fuller they will squeeze them tighter, and when at last the half-('usher hambul is dropered into the basket the berries alre almost ruined for market jurposes. Tot for \$lo per day would I premit such a person to pick for me, fir he not only takes filty per cent from the price of the fruit, but gives my bramd a bad reputation. If possible the grower should carefully 
select his pickers and have them subscribe to a few plitin rules like the following.

1. The berries must be piclied with the thumb and fore finger nails and not held in the hand but droppeel into the baskets at once.

2. No green, decayed or muddy berries will be received.

3. There must be no getting down upon all fours in the beds, thus crushing both green and ripe fruit.

4. There must be no "topping" ofl" with large berries, and the fruit must be equally good all through the basket.

In the early pickings of Wilsons when many of the herries are of good size, and of all the large, choice kinds, it is best to make two grates, putting the large and small by themselves. and lieeping varieties separate. A small frame with short legs at each corner and a handle is a convenient anpliance to hold six or more biskiets while picking. Give to ench picker two sets of baskets, one for the small, and one for the latrge berries, and pay equally for both so that there may be no motive to thwart your purpose; two cents per quart is the usual price. ILave two styles of tickets, red and hlue, for instanee, the red having a higher value aml given to those who bring the berries to the platce of packing in good order, according to rule; let the baskets not pickerl in conformity to the rules be receipted for with the blue tickets. Receiving many of the latter soon becomes a kind of discrace, ant thus you appeal to the principle of self-respect as well as selfinterest. Get rid of those who persist in careless picking as soon as possible. Insist that the baskets be full and romderl up. and the firuit equal in quality down to the bottom. As far as posibible let the hulls be kown, out of sight, and only the finit showing. If you have herries that are extrab fine it will pay you fo pick and preti them yourself, or have some one do it that wan he depended npon. Do not pick the fruit, if you can help it. When it is wet with dew or rain; still there are times when this must be done to sarse it. Fever let the biskliets or crates stami longe in the sum and wind, as the berries so treated soon become dull 
and finder. As soon as a crate is filled put it under cover in a cool place till shipped to murket. Insist upon careful, gentle

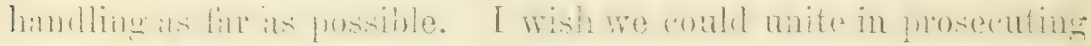
parties who spoil oul fruit by tossing the crates about. That commission men are but human is a fact that will scrircely be disputer, and it will, perhaps, be best to try sereral and deal with those who do the best for you.

Profity - Vo artain infimmation (and be given upon this suh-

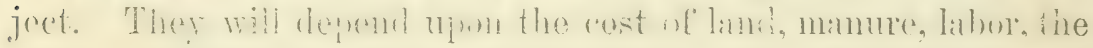
number of bushels raised per acre, prices, ete. IVm. Parry says that stranberies will par him at six rents per quat. but I lo not think they would pay me at that price. I should think that a

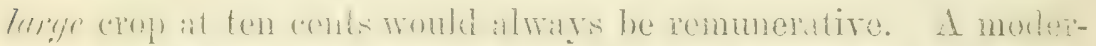

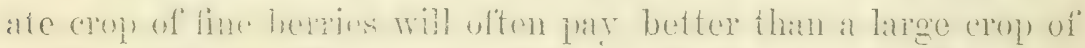

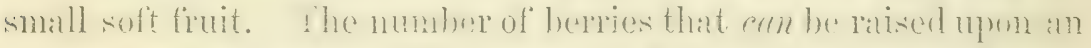

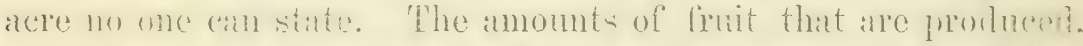

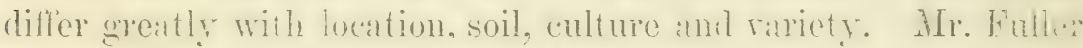

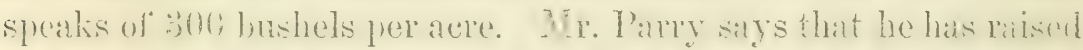

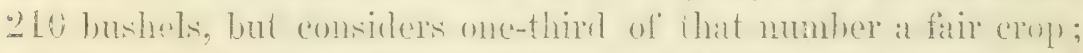
while in the light simly soil of Delawitre ti bushels are rearateri

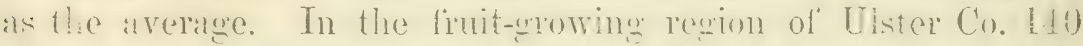

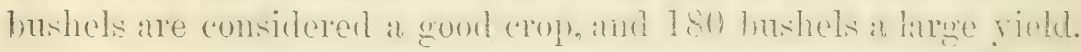
I have raised 95 bushels on two-thirds of an acre. As we have intimated before, the quantity mised dow not depend so much

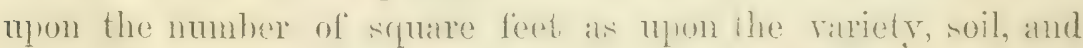
cultivation. There have been instances where an acre of straw-

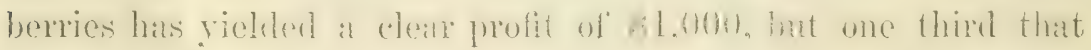

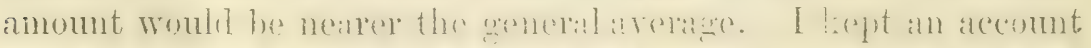

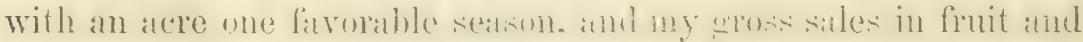
plants was $\$ 1,400$, about $\$ 800$ of which was profit. Wm. Parry, of Cinnaminson, N. J., thus records his experience, "For

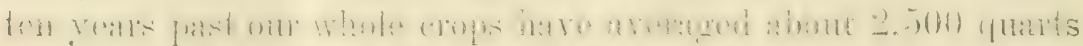

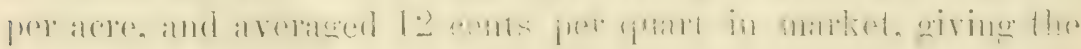
following resuits : 
Commision, 10 per rent........................

Picking, at 2 cents.......................... 50.00

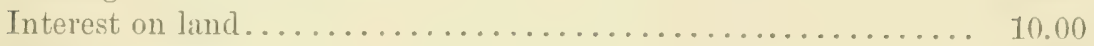

Manure. . . . . . . . . . . . . . . . . . . . . . . . 20.0

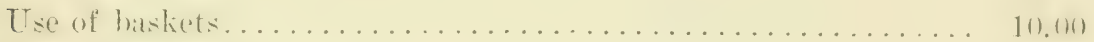

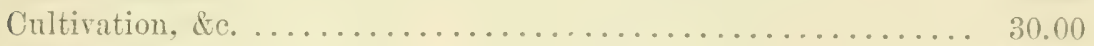

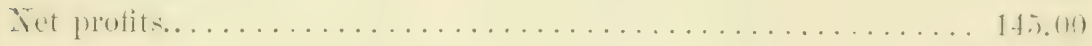

Gross proceeds, 2,000 quarts, at 12 cents...........\$300.00

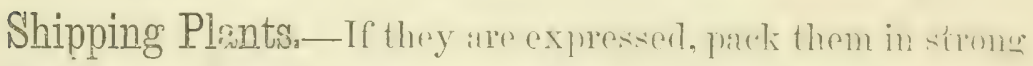
shallow boxes, tied loosely in bumbles of filty. with the rasts down and the topse up and exposed to tha air. Tn coul weathere a layer of dimp moss over the bottom of the box, and betserent each row of burdles, will preserve them. Then slits arre miled closely across the top of the box. If the plants are sant in hot, dry weather, it is best to dip each one in a mul pastes, that will coat the roots, and place them very loosely in the box to prevent. heating; and then use moss. chaff. or the finc rakings of the lawn. as before. Or in cool weather they may be packerl in barrels, first boring or cutting many holes in the siles for air. Place at layer of moss. then a layer of plants in a circle. With the toje out toward the sides. continue these layers till the barred is full. 'ilhus

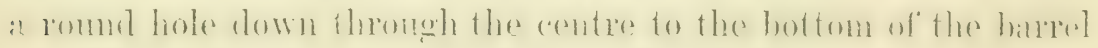
is left for circulation with an opening in the cover or head over this brathiug place. Whan the plints ane sent by mail. way the roots in damp, (not wet, dripping) moss, then encase them in oiled paper, with a neat wrapper of brown paper over this. Leare a little of the top exposed for air, and to show what the package contains, and tie on a card of direction. If the govern-

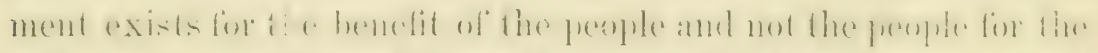

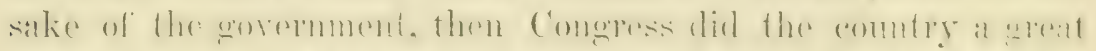

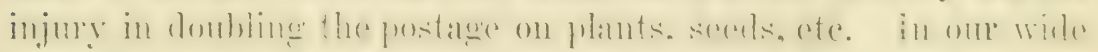

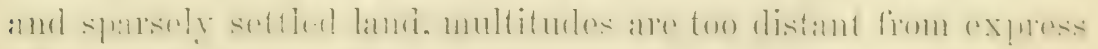
offices to find them of any scrvice.

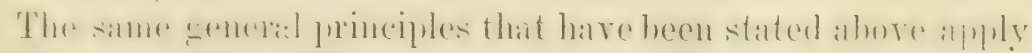
to all the other small firuits.

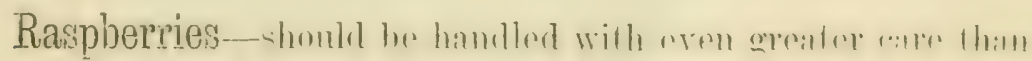




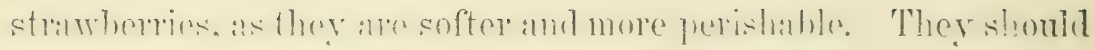

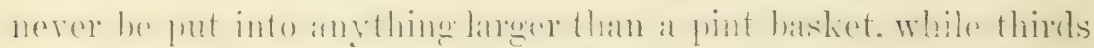

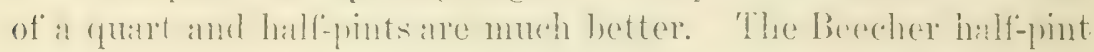
seems to be coming into livor, while the Ithitney thirls are chiefly used upon the Indson river. There is a wide shallow basket male in Fochester, that some growers think highly of. With

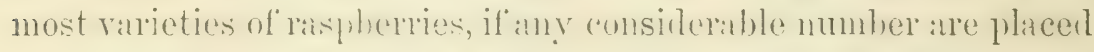
together they som become a solt, moully mass. The illeal raspberry bisket, therefore: is small. open, and shallow ; and the crates should jermit free cinculation. Tick the fruit when dry, and as soon as it is ripe, as orer-ripe berres decaly quickly. Keep raricties by themselves. Mr. Parry says that raspherries will pay at ten cents per quant, but I lo not think that any money cam be malle from them at less than twelve. They usually sell at much higher figures. IBhckalls, of late yeurs, have scarcely brought paymg prices in Now rork market. The following statenent shows what a diflurence rariety and therefore quality makes in the same market. “On the Tth elaty of July, 1871, raspheries were sold at wholesale, in Philadelphia, as follows, viz.:

Black Cap......................... 5 cents per quart.

Philadelphia..................... 8 do.

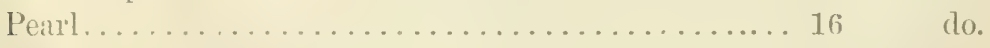

Susqueco, or Brandywine.................. 30 do.

Hormet........................... 60 do.

Bhakherres sell well in hoth (puart and pint baskets, but if one is semling a long distance, pints will anry the fruit in better condition.

The best methou ol shipling ammats is to have tills, or shallow boxes, two or four in number, fitting in one is berry crates. which can thus be mate to serve a douhle purpose. Mark on these tills the net weight of the fruit. For lanere cherry curants, quart ane verbena baskets are often used. Many like a long

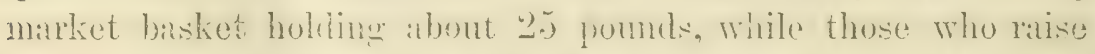
graples often make the same shallow boxes answer for both.

Guoseberries are shiphed in all kinds of packitges, fiom hatr- 
rels to quart boxes. I prefer a crate with tills for both gooseberries and currants. These two fruts, especially the latters atre becoming increasingly profitable every year.

In summing up it may be briefly stated that with all firuits, and in all the laree markets. beanty, tize, and goml kereping qualities are the points which are chicfly consinered. Very few

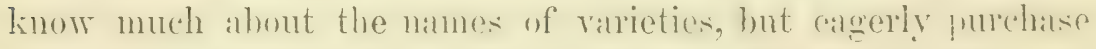
that which alpease the most attractive. The grower who and make his crates of berries when opened look hetter than any other's near, will always receive good prices. If he tops off poor fruit with large berries, he will soon scarcely find a market at all. If he always fills his baskets well and honestly,

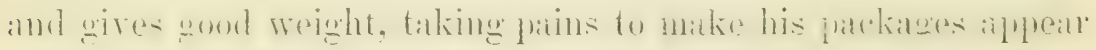
athative, his fint will soon be in much demand and spoken for in advance. 


\section{AST WORDS.}

In bowme myself out from this brief interview with the rearler, I will merely adl that I have tried to make my precening words simple and to the point-helpful. I lay no claim whaterer to seientific and exhaustive thoroughness. It is rather as if I had sat lown and chatted with the reader for an hour, telling him what little I knew, and auswering his supposed questions. If he had been actually present he would have asked scores that I could not have answered. But for practical purposes I have honestly tried to be plain, accurate, and sugrestive, so that efen the novice could understand what he must do to succeed with the most delicious and wholesome fruits of the year. In just distrust of my own judgment and knowledge, I have rear all the preceding pages, except those treating of markets, etc., to Charles Downing, who is rightfully considered one of the rery chief authorities upon these subjects. But where I am in futt the errors are my own.

It is one of the hopes of the future that I may be able to observe carefully the many new rarieties of fruit that are claiming attention, and by reporting as accurately as possible mon them ammally, enable others to judge of their value. I also hope to give from time to time the results of experiments, amm my own, and the experience of others in the rarious methork of culture. But whether such expectations will ever he fulfilled is a question that time only can answer.

If through the influence of this mannal more ripe and delicious fruits appear upon your dialy boand, you will find that you have followed the advice of a friend. 


\section{PLAY AND PROFIT IN MY GARDEN.}

THE author tells in this volume the story of a successful experience in gardening.

From 21/4 acres $\$ 2,000$ worth of fruit and vegetables were sold during the year of 1871 , and in addition there was a most abundant home supply.

The aim of the book is to relate, in light and simple style, how this was done by a professional man gardening for recreation, and averaging not much over an hour a day of his own time to his garden.

While the writer seeks to give a clear record of experience and the most practical advice, he also endeavors to shun as far as possible a dry, didactic form of writing.

TWO THOUSAND SEVEN HUNDRED DOLLARS' worth of fruit and regetables were sold from this garden, increased to three acres, under the same general management, in 1874 .

\section{OPINIONS OF THE PRESS.}

"The author takes us to his garden on the rocky hill-sides in the vicinity of West Point, and shows us how out of it, after four years' experience, he evoked a profit of $\$ 1,000$, and this while carrying on pastoral and literary labors *** It is very rare that so much literary taste and skill are mated to so much agricultural experience and practical good sense."-Harper's Magazine.

"This book is as poetical as it is practical. Still he is no dreamer. He goes into every essential detail with as much minuteness and precision as if he were writing a manual for the practical farmer. Indeed few works professedly devoted to agriculture give more sound and valuable information on the secret of winning golden harvests from the soil than this brief idyllic sketch." $-N$. Y. Tribune.

"A very charming book, not only by reason of its pleasant style, but for its quiet, refined humor and fund of really useful information on the subject of gardening."Boston Gazette.

"It deserves to stand side by side with 'My Summer in a Garden." - Christiun Register.

"A fresh, lively work."-N. Y. Observer.

"One reads without weariness and learns much of practical value."-Ohicago Evening Journal.

"Full of information. Explains just what the reader wishes to know. We most heartily commend it."-Providence Evening Press.

"A chatty, sensible, profitable book."-Cleveland Herculd.

"The book gives much valuable information, and gives it in the pleasantest manner imaginable."-Detroit Daily Union.

Mailed on receipt of price, $\$ 1.50$. 


\section{BARRIERS BURNED AWAY.}

20th Thousand. Price, \$1.25.

\section{OPINIONS OF THE PRESS.}

"When so much trashy and soul enervating literature is issued under the head of religious novels, it is refreshing to see one like the Rev. Mr. Roe's Barriers Burned Away, written with an earnest purpose. Sensationsl, and yet to good effects, -inartistic as might be looked for in the young author's first attempt, and yet unhackneyed, lively, and fascinating."-Springfield Republican.

- The characters are delineated with truthfulness and consistency. In their conception the author shows equal originality and boldness. Even Old Bill Cronk, the rough, hard-swearing, hard-drinking, hig-fisted, big-hearted Western drover, could not be spared from the scene."-New York Tribune.

We congratulate Mr. Roe upon his story of the day."-New York Observer.

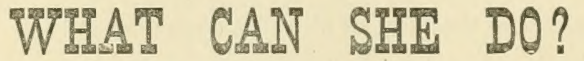

\section{4th Thousand. Price, \$1.\%.}

"The moral purpose of this book is amply worthy of the author's zeal. It is that young women should be educated in such a way that if left without money they shall be able to support themselves. Mr. Roe is especially severe upon our American vice of "pride of occupation." "-N. Y. Evening Post.

We consider that parents are indebted to the author for the most practical story of the day."Philadelphia Agle.

His works have an honest, healthy tone, and a purpose. His narrative is full of interest-in the present case unnsually so. We must not forget in particular to allude to his always charming bits of conntry life ; his gardening at once poetic and profitable." $-N$. Y. Evening Express.

"The narrative is fascinating." - Chicago Advance.

"An exceedingly well-written story."-Churchman.

\section{OPENING OT A CHESTNUT BURR:}

17th Thousand. Price, \$1.75.

"In The Opening of a Chestnut Burr, Mr. Roe has made a marked advance upon his two previous stories. He has already exhibited a remarkable power of deseription, which in this volume he uses with good effect in the scenes of fire and shipwreck. It is thoronghly religions, thoroughly Christian both in tone and teaching."-Harper's Magazine.

"The character of the selfish, morbid. cynical hero, and his gradual transformation under the influence of the sweet and high-spirited heroine, are portrayed with a masculine firmness, which is near akin to power, and some of the conversations are animated and admirable."-Atlantic Monthly.

The most able story that we have had from the pen of Mr. Roe. It is also the best of the so-called religions novels published of late."-The Christian Union.

There are many stirring and dramatic scenes in the story, while its quieter phases are not wanting in grace and sweetness." --Boston Traveller.

Mr. Roe has laid out his greatest power in depicting the character of the heroine, who is a model of saintly purpose and ardent piety without losing the peculiar charms of female loveliness. He is strong in his delineation of character. All his personages have a elear, sharp-cut individuality, and make a fresh and deep impression on the reader."--New York T'ribune.

\section{FROM JEST TO EARNEST.}

17th Thousand. Price, \$1.75.

"His plots are never commonplace. The change in Lottie's character is well delineated, and with a naturalness and artistic skill which we do not often find in the so-called religious novels." - Harp. Mag.

"It is surprising to find how genuinely interesting his stories always are. There is nothing of the vulgarly sensational about them,"-Eclectic Magazine.

"Mr. Roe's books are religious novels in perhaps the best sense of the term." -Zion's Herald, Boston.

A simple, pure story, such as Mr. Roe has always written, is one of the most potent vehicles of moral and religious training that can be employed."-Buffalo Daily Courier.

"Mr. Roe's works have had a fine, noble purpose, each and all. The present story is an excellent one-of high tone and deep religious strength."-Boston Evening Traveller.

"It is a thoroughly good story because pervaded by an influence thoroughly pure."-Am. Rural Home.

":The hero is simple, strong, and manly: much such a man as Mr. Lincoln must have been had he turned his attention to theology instead of politics." - New York World.

"A bright, vivacious story, full of wit and even frolic."-Portland Transcript.

"He vindicates his right to use the talent which God has given him for the instruction and interest of the thousands who read his works."-New York Evangelist.

SEVENTY-TWO THOUSAND of the five books named above have been sold in this country in less than three and a half years. They have also all been published both in book and serial form in England.

Any or all of the above named books will be mailed on the receipt of price.

Address,

E. P. ROE

CornWALt-ON-THE-HUdson, New YoRK. 


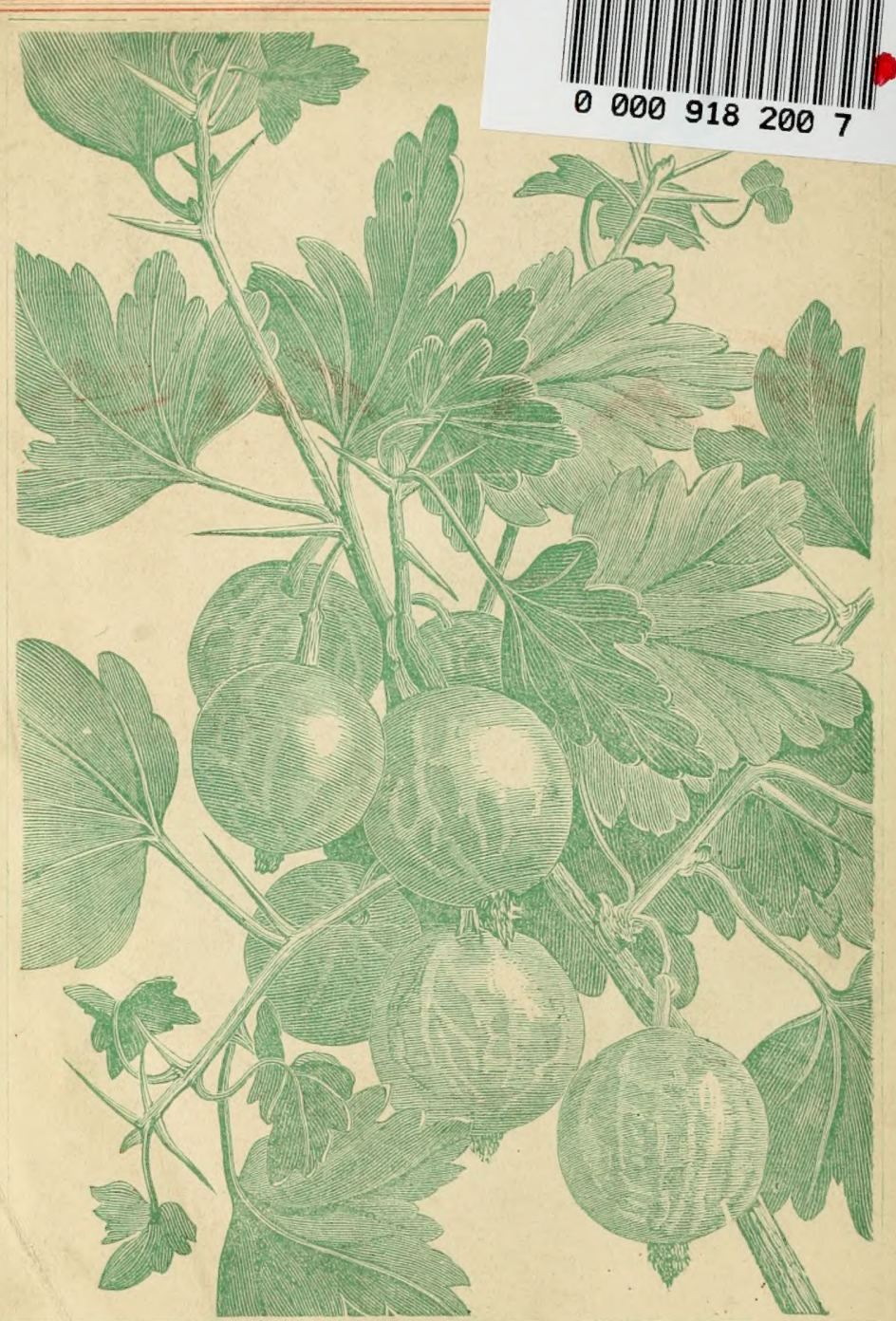

ROE'S NTHW SFFDIING GOOSEEFERY

(For full description and history see the chapter within upon the Gooseberry.) STRAWBERRY AND RASPBERRY PLANTS

\section{And Other Small Fruits in Large or Small Quantities for Sale in their Season.}

Circular and Price List Mailed Free on Application.

If you have no land, do the best you can in the markets. If you have but a few square feet, I commend to you the words of the Editor of the American Agriculturist: "The unfortunate people who buy their fruit do not know what a strawberry is." Address,

\section{F. P. ROF,

